\title{
Um discurso sobre as Ciências na transição para uma ciência pós-moderna
}

\author{
Boaventura de Sousa Santos*
}

Estamos a doze anos do final do século $\mathrm{XX}$. Vivemos num tempo atônito que ao debruçar-se sobre si próprio descobre que os seus pés são um cruzamento de sombras, sombras que vêm do passado que ora pensamos já não sermos, ora pensamos não termos ainda deixado de ser, sombras que vêm do futuro que ora pensamos já sermos, ora pensamos nunca virmos a ser. Quando, ao procurarmos analisar a situação presente das ciências no seu conjunto, olhamos para o passado a primeira imagem é talvez a de que os progressos cientificos dos últimos trinta anos são de tal ordem dramáticos que os séculos que nos precederam - desde 0 século XVI, onde todos nós, cientistas modernos, nascemos, até ao próprio século XIX - não são mais que uma pré-história longínqua. Mas se fecharmos os olhos e os voltarmos a abrir, verificamos com surpresa que os grandes cientistas que estabeleceram e mapearam o campo teórico em que ainda hoje nos movemos viveram ou trabalharam entre o século XVIII e os primeiros vinte anos do século $\mathrm{XX}$, de Adam Smith e Ricardo a Lavoisier e Darwin, de Marx e Durkheim a Max Weber e Pareto, de Humboldt e Planck a Poincare e Einstein. E de tal modo é assim que é possível dizer que em termos científicos vivemos ainda no século XIX e que o século XX ainda não começou, nem talvez comece antes de terminar. E se, em vez de no passado, centrarmos o nosso olhar no futuro, do mesmo modo duas imagens contraditorias nos ocorrem alternadamente. Por um lado, as potencialidades da tradução tecnológica dos conhecimentos acumulados fazem-nos crer no limiar de uma sociedade de comunicação e interativa libertada das carências e inseguranças que ainda hoje compõem os dias de muitos de nós: o século XXI a começar antes de começar. Por outro lado, uma reflexão cada vez mais aprofundada sobre os limites do rigor cientifico combinada com os perigos cada vez mais verossímeis da catástrofe ecologica ou da guerra nuclear fazem-nos temer que o século XXI termine antes de começar.

Recorrendo à teoria sinergética do físico teorico Hermann Haken, podemos dizer que vivemos num sistema visual muito instável em que a mínima flutuação da nossa percepção visual provoca rupturas na simetria do que vemos. Assim, olhando a mesma figura, ora vemos um vaso grego branco recortado sobre um fundo preto, ora vemos dois rostos gregos de perfil, frente a frente, recortados sobre um fundo branco. Qual das imagens é verdadeira? Ambas e nenhuma. Esta a ambigüidade e a complexidade da situação do tempo presente, um tempo de transição, síncrone com muita coisa que está além ou aquém dele, mas descompassado em relação a tudo o que o habita.

Tal como noutros períodos de transição, difíceis de entender e de percorrer, $e$ necessário voltar às coisas simples, à capacidade de formular perguntas simples, perguntas que, como Einstein costumava dizer, só uma criança pode fazer mas que, depois de feitas, são capazes de trazer uma luz nova à nossa perplexidade. Tenho comigo uma criança que há precisamente duzentos e trinta e oito

* A visita do prof. Boaventura contou com o apoio da FAPESP. As reflexões epistemológicas deste texto estão tratadas com maior amplitude no livro Introdução a uma Ciência Pós-Moderna, a ser publicado pela Editora Graal. 
anos fez algumas perguntas simples sobre as ciências e os cientistas. Fê-las no início de um ciclo de produção científica que muitos de nós julgam estar agora a chegar ao fim. Essa criança E Jean-Jacques Rousseau. No seu célebre Discours sur les Sciences et les Arts (1750)

Rousseau formula várias questões enquanto responde à que, também razoavelmente infantil, lhe fora posta pela Academia de Dijon1. Esta última questão rezava assim: o progresso das ciências e das artes contribuirá para purificar ou para corromper os nossos costumes? Trata-se de uma pergunta elementar, ao mesmo tempo profunda e fácil de entender.Para lhe dar resposta do modo eloquiente que the mereceu o primeiro prêmio e algumas inimizades Rousseau fez as seguintes perguntas não menos elementares: há alguma relação entre a ciência e a virtude? Há alguma razão de peso para substituirmos o conhecimento vulgar que temos da natureza e da vida e que partilhamos com os homens e mulheres de nossa sociedade pelo conhecimento cientifico produzido por poucos e inacessível à maioria? Contribuirá a ciência para diminuir o fosso crescente na nossa sociedade entre o que se é e o que se aparenta ser, o saber dizer e o saber fazer, entre a teoria e a prática? Perguntas simples a que Rousseau responde, de modo igualmente simples, com um redondo não.

Estávamos então em meados do século XVIII, numa altura em que a ciência moderna, saída da revolução científica do século XVI pelas mãos de Copérnico, Galileu e Newton, começava a deixar os cálculos esotéricos dos seus cultores para se transformar no fermento de uma transformação técnica e social sem precedentes na história da humanidade. Uma fase de transição, pois, que deixava perplexos os espiritos mais atentos e os fazia refletir sobre os fundamentos da sociedade em que viviam e sobre $o$ impacto das vibrações a que eles iam ser sujeitos por via da ordem científica emergente. Hoje, duzentos anos volvidos, somos todos protagonistas e produtos dessa nova ordem, testemunhos vivos das transformações que ela produziu.
Contudo, não o somos, em 1988, do mesmo modo que o éramos há quinze ou vinte anos. Por razões que alinho adiante, estamos de novo perplexos, perdemos a confiança epistemológica; instalou-se em nós uma sensação de perda irreparável tanto mais estranha quanto não sabemos ao certo o que estamos em vias de perder; admitimos mesmo, noutros momentos. que essa sensação de perda seja apenas a cortina de medo atrás da qual se escondem as novas abundâncias da nossa vida in dividual e coletiva. Mas mesmo aí volta a perplexidade de não sabermos o que abundará em nós nessa abundância.

Daí a ambigüidade e complexidade do tempo científico presente a que comecei por aludir. Daí também a idéia, hoje partilhada por muitos, de estarmos numa fase de transição. Daí finalmente a urgência de dar resposta a perguntas simples, elementares, inteligíveis. Uma pergunta elementar é uma pergunta que atinge o magma mais profundo da nossa perplexidade individual e coletiva com a transparência técnica de uma fisga.

Foram assim as perguntas de Rousseau; terão de ser assim as nossas. Mais do que isso, duzentos e tal anos depois, as nossas perguntas continuam a ser as de Rousseau. Estamos de novo regressados à necessidade de perguntar pelas relações entre a ciência e a virtude, pelo valor do conhecimento dito ordinário ou vulgar que nós, sujeitos individuais ou cole tivos, criamos e usamos para dar sentido às nossas práticas e que a ciência teima em considerar irrelevante, ilusório e falso; e temos finalmente de perguntar pelo papel de todo o conhecimento científico acumulado no enriquecimento ou no empobrecimento prático das nossas vidas, ou seja, pelo contributo positivo ou negativo da ciência para a nossa felicidade. A nossa diferença existencial em relação a Rousseau é que, se as nossas perguntas são simples, as respostas sê-lo-ão muito menos. Estamos no fim de um ciclo de hegemonia de uma certa ordem científica. As condições epistêmicas das nossas perguntas estão inscritas no avesso dos conceitos que utilizamos para lhes dar resposta. $\hat{E}$ necessário um esforço de desvendamento conduzido sobre um fio de navalha entre

1 Jean-Jacques Rousseau, Discours sur les Sciences et les Arts, in Oeuvres Complètes, vol. 2, Paris, Seuil, 1971, p. 52 e segs. 
a lucidez e a ininteligibilidade da resposta. São igualmente diferentes e muito mais complexas as condições sociologicas e psicológicas do nosso perguntar. E muito diferente perguntar pela utilidade ou pela felicidade que o automovel me pode proporcionar se a pergunta é feita quando ninguém na minha vizinhança tem automóvel, quando toda a gente tem exceto eu ou quando eu próprio tenho carro há mais de vinte anos.

Teremos forçosamente de ser mais rousseaunianos no perguntar do que no responder. Começarei por caracterizar sucintamente a ordem científica hegemónica. Analisarei depois os sinais da crise dessa hegemonia, distinguindo entre as condições teóricas e as condições sociológicas da crise. Finalmente especularei sobre o perfil de uma nova ordem científica emergente, distinguindo de novo entre as condições teóricas e as condições sociológicas da sua emergência. Este percurso analítico será balizado pelas seguintes hipoteses de trabalho: primeiro, começa a deixar de fazer sentido a distinção entre ciências naturais e ciências sociais; segundo, a síntese que há que operar entre elas tem como pólo catalisador as ciências sociais; terceiro, para isso, as ciências sociais terão de recusar todas as formas de positivismo lógico ou empírico ou de mecanicismo materialista ou idealista com a conseqüente revalorização do que se convencionou chamar humanidades ou estudos humanísticos; quarto, esta síntese não visa uma ciência unificada nem sequer uma teoria geral, mas tão-só um conjunto de galerias temáticas onde convergem linhas de água que ate agora concebemos como objetos teóricos estanques; quinto, à medida que se der esta síntese, a distinção hierárquica entre conhecimento científico e conhecimento vulgar tenderá a desaparecer e a prática será o fazer e o dizer da filosofia da prática.

\section{O Paradigma Dominante}

O modelo de racionalidade que preside à ciência moderna constituiu-se a partir da revolução científica do século XVI e foi desenvolvido nos séculos seguintes basicamente no domínio das ciências naturais. Ainda que com alguns prenúncios no século XVIII, é só no século XIX que este modelo de racionalidade se estende às ciências sociais emergentes. A partir de então pode falar-se de um modelo global de racionalidade científica que admite variedade interna mas que se distingue $e$ defende, por via de fronteiras ostensivas e ostensivamente policiadas, de duas formas de conhecimento não-científico (e, portanto, irracional) potencialmente perturbadoras e intrusas: o senso comum e as chamadas humanidades ou estudos humanisticos (em que se incluiram, entre outros, os estudos históricos, filológicos, jurídicos, literários, filosóficos e teológicos).

Sendo um modelo global, a nova racionalidade científica é também um modelo totalitário, na medida em que nega o caráter racional a todas as formas de conhecimento que se não pautarem pelos seus princípios epistemológicos e pelas suas regras metodológicas. É esta a sua caracteristica fundamental e a que melhor simboliza a ruptura do novo paradigma científico com os que o precedem. Está consubstanciada, com crescente definição, na teoria heliocêntrica do movimento dos planetas de Copernico, nas leis de Kepler sobre as órbitas dos planetas, nas leis de Galileu sobre a queda dos corpos, na grande síntese da ordem cósmica de Newton e finalmente na consciência filosófica que the conferem Bacon e sobretudo Descartes. Esta preocupação em testemunhar uma ruptura fundante que possibilita uma e só uma forma de conhecimento verdadeiro está bem patente na atitude mental dos protagonistas, no seu espanto perante as proprias descobertas e a extrema e ao mesmo tempo serena arrogância com que se medem com os seus contemporâneos. Para citar apenas dois exemplos, Kepler escreve no seu livro sobre a Harmonia do Mundo publicado em 1619, a propósito das harmonias naturais que descobrira nos movimentos celestiais: "Perdoai-me mas estou feliz; se vos zangardes eu perseverarei; (. . .) O meu livro pode esperar muitos séculos pelo seu leitor. Mas mesmo Deus teve de esperar seis mil anos por aqueles que
$O$ modelo de racionalidade que preside à ciência moderna constituiuse a partir da revoluçâo científica do século XVI e foi desenvolvido nos séculos seguintes basicamente no dominio das ciências naturais. 
pudessem contemplar o seu trabalho"2. Por outro lado, Descartes, nessa maravilhosa autobiografia espiritual que é o Discurso do Método e a que voltarei mais tarde, diz, referindo-se ao método por si encontrado: "Porque já colhi dele tais frutos que embora no juizo que faço de mim proprio procure sempre inclinar-me mais para o lado da desconfiança do que para o da presunção, e embora, olhando com olhar de filosofo as diversas ações e empreendimentos de todos os homens, não haja quase nenhuma que não me pareça vã e inútil, não deixo de receber uma extrema satisfação com o progresso que julgo ter feito em busca da verdade e de conceber tais esperanças para o futuro que. se entre as ocupaçôes dos homens, puramente homens, alguma há que seja solidamente boa e importante, ouso crer que é aquela que escolli," ${ }^{3}$.

Para compreender esta confiança epistemológica é necessário descrever, ainda que sucintamente, os principais traços do novo paradigma científico. Cientes de que o que os separa do saber aristotélico e medieval ainda dominante não é apenas nem tanto uma melhor observação dos fatos como sobretudo uma nova visão do mundo e da vida, os protagonistas do novo paradigma conduzem uma luta apaixonada contra todas as formas de dogmatismo e de autoridade. O caso de Galileu é particularmente exemplar, e é ainda Descartes que afirma: "Eu não podia escolher ninguém cujas opiniōes me parecessem dever ser preferidas às dos outros, e encontrava-me como que obrigado a procurar conduzir-me a mim próprio" 4 . Esta nova visão do mundo e da vida reconduz-se a duas distinções fundamentais, entre conhecimento científico e conhecimento do senso comum, por um lado. e entre natureza e pessoa humana, por outro. Ao contrário da ciência aristotélica, a ciência moderna desconfia sistematicamente das evidências da nossa experiência imediata. Tais evidências, que estão na base do conhecimento vulgar, são ilusórias. Como bem salienta Einstein no prefácio ao Diálogo sobre os Grandes Sistemas do Mundo, Galileu esforça-se denodadamente por demonstrar que a hipótese dos movimentos de rotação e de translação da terra não é refutada pelo fato de não observarmos quaisquer efeitos mecânicos desses movimentos, ou seja, pelo fato de a terra nos parecer parada e quieta ${ }^{5}$. Por outro lado, é total a separação entre a natureza e o ser humano. A natureza é tão-só extensão e movimento; é passiva, eterna e reversível, mecanismos cujos elementos se podem desmontar e depois relacionar sob a forma de leis; não tem qualquer outra qualidade ou dignidade que nos impeça de desvendar os seus mistérios, desvendamento que não é contemplativo, mas antes ativo, já que visa conhecer a natureza para a dominar e controlar. Como diz Bacon, a ciência fará da pessoa humana "o senhor e o possuidor da natureza" 6 .

Com base nestes pressupostos o conhecimento científico avança pela observação descomprometida e livre, sistemática e tanto quanto possível rigorosa dos fenômenos naturais. $\mathrm{O}$ Novum Organum opõe a incerteza da razão entregue a si mesma à certeza da experiência ordenada ${ }^{7}$. Ao contrário do que pensa Bacon, a experiência não

2 Consultada a edição alemã (introduçāo e tradução de Max Caspar), Johannes Kepler, Welt-Harmonik. Muntque, Verlag Oldenhourg, 1939, p. 280.

3 Descartes, Discurso do Método e as Paixðes da Alma. Lisboa, Sá da Costa, 1984, p. 6.

4 Descartes, ob. cit., p. 16.

5 Einstein in Galileu, Dialogue Concerning the Two Chief World Systems. Berkeley, University of California Press, 1970, p. xiiii.

6 Consultada a edição espanhola (preparada e traduzida por Gallach Palés), F. Bacon, Novum Organum. Madrid, Nueva Biblioteca Filosófica, 1933. Para Bacon "a senda que conduz o homem ao poder e a que o conduz à ciência estäo muito próximas, sendo quase a mesma" (p. 110). Se o objetilo da ciência é dominar a natureza não é menos verdade que "só podemos vencer a natureza obedecendo-lhe" (p. 6, grifo meu), o que nem sempre tem sido devidamente salientado nas interpretaçōes da teoria de Bacon sobre a ciência.

7 Cf. A. Koyré, Considerações sobre Descartes. Lisboa, Presença, 1981, p. 30. 
dispensa a teoria prévia, o pensamento dedutivo ou mesmo a especulação, mas força qualquer deles a ño dispensarem, enquanto instância de confirmação última, a observação dos fatos. Galileu só refuta as deduções de Aristóteles na medida em que as acha insustentáveis e é ainda Einstein quem nos chama a atenção para o fato de os métodos experimentais de Galileu serem tão imperfeitos que só por via de especulações ousadas poderia preencher as lacunas entre os dados empíricos (basta recordar que não havia medições de tempo inferiores ao segundo) ${ }^{8}$. Descartes, por seu turno, vai inequivocamente das idéias para as coisas e não das coisas para as idéias e estabelece a prioridade da metafísica enquanto fundamento último da ciência.

As idéias que presidem à observação e à experimentação são as idéias claras e simples a partir das quais se pode ascender a um conhecimento mais profundo e rigoroso da natureza. Essas idéias são as idéias matemáticas. A matemática fornece à ciência moderna, não só o instrumento privilegiado de análise, como tambem a lógica da investigação, como ainda o modelo de representação da própria estrutura da matéria. Para Galileu, o livro da natureza está inscrito em caracteres geomé tricos 9 e Einstein não pensa de modo diferente 10 . Deste lugar central da matemática na ciência moderna derivam duas conseqüências principais. Em primeiro lugar, conhecer significa quantificar. $O$ rigor científico afere-se pelo rigor das medições. As qualidades intrínsecas do objeto são, por assim dizer, desqualificadas e em seu lugar passam a imperar as quantidades em que eventualmente se podem traduzir. $O$ que não e quantificável e cientificamente irrelevante. Em segundo lugar, o método científico assenta na redução da complexidade. $O$ mundo é complicado e a mente humana não o pode compreender comple tamente. Conhecer significa dividir e classificar para depois poder determinar relações sistemáticas entre o que se separou. Já em Descartes uma das regras do Método consiste precisamente em "dividir cada uma das dificuldades ... em tantas parcelas quanto for possível e requerido para melhor as resolver" 11 . A divisão primordial é a que distingue entre "condições iniciais" e "leis da natureza". As condições iniciais são o reino da complicação, do acidente e onde é necessário selecionar as que estabelecem as condições relevantes dos fatos a observar; as leis da natureza são o reino da simplicidade e da regularidade onde é possível observar e medir com rigor. Esta distinção entre condições iniciais e leis da natureza nada tem de "natural". Como bem observa Eugene Wigner, é mesmo completamente arbitrária 12 . No entanto, é nela que assenta toda a ciência moderna.

A natureza teórica do conhecimento científico decorre dos pressupostos epistemologicos e das regras metodológicas já referidas. $\vec{E}$ um

8 Einstein, ob. cit., p. XIX.

9 Entre muitos outros passos do Diálogo sobre os Grandes Sistemas, cf. a seguinte fala de Salviati: "No que respeita dे compreensão intensiva $e$ na medida em que este termo denota a compreensāo perfeita de alguma proposiçấ, digo que a inteligência humana compreende algumas delas perfeitamente, e que, portanto, a respeito delas tem uma certeza täo absoluta quanto a própria natureza. Tais são as prop 'siçôes das ciências matemdticas, isto $\dot{e}$ da geometria e da aritmética nas quais a inteligência divina conhece infinitamente mais proposiçöes porque as conhece todas. Mas no que respeita àquelas poucas que a inteligência humana compreende, penso que o seu conhecimento é igual ao Divino em certeza objetiva porque, nesses casos, consegue compreender a necessidade para além da qual não há maior certeza". Galileu, ob. cit., p. 103.

10 A admiração de Einstein por Galileu está bem expressa no prefacio referido na nota $5 . O$

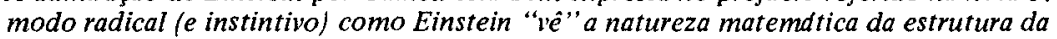
matéria explica em parte a sua longa batalha sobre a interpretaçāo da mecânica quântica (especialmente contra a interpretação de Copenhague). Cf. B. Hoffmann, Albert Einstein, Creator and Rebel, Nova Iorque, New American Library, 1973, p. 173 e segs.

11 Descartes, ob. cit., p. 17.

12 E. Wigner, Symmetries and Reflections. Scientific Essays. Cambridge, Cambridge University Press, 1970, p. 3 . 
conhecimento causal que aspira à formulação de leis, à luz de regularidades observadas, com vista a prever o comportamento futuro dos fenômenos.

A descoberta das leis da natureza assenta, por um lado, e como já se referiu, no isolamento das condições iniciais relevantes (por exemplo, no caso da queda dos corpos, a posição inicial e a velocidade do corpo em queda) e, por outro lado, no pressuposto de que $o$ resultado se produzirá independentemente do lugar e do tempo em que se realizarem as condições iniciais. Por outras palavras, a descoberta das leis da natureza assenta no princípio de que a posição absoluta e o tempo absoluto nunca são condições iniciais relevantes. Este princípio é, segundo Wigner, o mais importante teorema da invariância na física clássica 13 .

As leis, enquanto categorias de inteligibilidade. repousam num conceito de causalidade escollhido, não arbitrariamente, entre os oferecidos pela física aristotélica. Aristóteles distingue quatro tipos de causa: a causa material, a causa formal, a causa eficiente e a causa final. As leis da ciência moderna são um

0 determinismo mecanicista é o horizonte certo de uma forma de conhecimento que se pretende utilitário e funcional, reconhecido menos pela capacidade de compreender profundamente $o$ real do que pela capacidade de $o$ dominar e transformar. No plano social, é esse também $\theta$ horizonte cognitivo mais adequado aos interesses $\mathrm{da}$ burguesia ascendente que via na sociedade em que compçava a dominar o estádio final da evolução da humanidade tipo de causa formal que privilegia o como funciona das coisas em detrimento de qual o agente ou qual o fim das coisas. E por esta via que o conhecimento científico rompe com o conhecimento do senso comum. E que, enquanto no senso comum, e portanto no conhecimento prático em que ele se traduz, a causa e a intenção convivem sem problemas, na ciência a determinação da causa formal obtém-se com a expulsão da intenção. E este tipo de causa formal que permite prever e, portanto, intervir no real e que, em última instância, permite à ciência moderna responder à pergunta sobre os fundamentos do seu rigor e da sua verdade com o elenco dos seus êxitos na manipulação e na transformação do real.

Um conhecimento baseado na formulação de leis tem como pressuposto metateórico a idéia de ordem e de estabilidade do mundo, a idéia de que o passado se repete no futuro. Segundo a mecânica newtoniana, o mundo da matéria é uma máquina cujas operações se podem determinar exatamente por meio de leis físicas e matematicas, um mundo estático e eterno a flutuar num espaço vazio, um mundo que o racionalismo cartesiano toma cognoscivel por via da sua decomposição nos elementos que o constituem. Esta idéia do mundo-maquina é de tal modo poderosa que se vai transformar na grande hipotese universal da época moderna, o mecanicismo. Pode parecer surpreendente e até paradoxal que uma forma de conhecimento, assente numa tal visão do mundo, tenha vindo a constituir um dos pilares da idéia de progresso que ganha corpo no pensamento europeu a partir do século XVIII e que é o grande sinal intelectual da ascensão da burguesia 14 . Mas a verdade é que a ordem e a estabilidade do mundo são a pré-condição da transformação tecnológica do real.

O determinisıno mecanicista é o horizonte certo de uma forma de conhecimento que se pretende utilitário e funcional, reconhecido menos pela capacidade de compreender profundamente o real do que pela capacidade de o dominar e transformar. No plano social, é esse também o horizonte cognitivo mais adequado aos interesses da burguesia ascendente que via na sociedade em que começava a dominar o estádio final da evolução da humanidade (o estado positivo de Comte; a sociedade industrial de Spencer; a solidariedade orgânica de Durkheim). Daí que o prestígio de Newton e das leis simples a que reduzia toda a complexidade da ordem cósmica tenham convertido a ciência moderna no modelo de racionalidade hegemônica que a pouco e pouco transbordou do estudo da natureza para o estudo da sociedade. Tal como foi possível descobrir as leis da natureza, seria igualmente possível descobrir as leis da sociedade. Bacon, Vico e Montesquieu são os grandes precursores. Bacon afirma a plasticidade da natureza humana $e$, portanto, a sua perfectibilidade, dadas as condições

13 E. Wigner, ob. cit., p. 226.

$14 C f$., entre muitos, S. Pollard, The Idea of Progress. Londres, Penguin, 1971, p. 39. 
sociais, jurfdicas e politicas adequadas, condiçōes que é possivel determinar com rigor ${ }^{15}$. Vico sugere a existência de leis que governam deterministicamente a evoluçăo das sociedades e tornam possive] prever os resultados das açoes coletivas. Com extraordinária premoniçăo Vico identifica e resolve a contradição entre a liberdade $e$ a imprevisibilidade da açẫo humana individual $e$ a determinação $e$ previsibilidade da açáo coletiva 16 . Montesquieu pode ser considerado um precursor da sociologia do direito ao estabelecer a relação entre as leis do sistema juridico, feitas pelo homem, e as leis inescapaveis da natureza17.

No seculo XVIII este espírito precursor e ampliado e aprofundado e o fermento intelectual que daí resulta, as luzes, vai criar as condições para a emergencia das ciências sociais no século XIX. A consciencia filosofica da ciência moderna, que tivera no racionalismo cartesiano e no empirismo baconiano as suas primeiras formulaçő́es, veio a condensar-se no positivismo oitocentista. Dado que, segundo este, so há duas formas de conhecimento científico - as disciplinas formais da logica e da matemática e as ciências emprricas segundo o modelo mecanicista das ciencias naturais - as ciências sociais nasceram para ser empíricas. 0 modo como o modelo mecanicista foi assumido foi, no entanto, diverso. Distingo duas vertentes

principais: a primeira, sem dúvida dominante, consistiu em aplicar, na medida do possível, ao estudo da sociedade todos os princípios epistemológicos e metodológicos que presidiam ao estudo da natureza desde 0 seculo XVI; a segunda, durante muito tempo marginal mas hoje cada vez mais seguida, consistiu em reivindicar para as ciências sociais um estatuto epistemológico e metodológico próprio, com base na especificidade do ser humano e sua distinção polar em relação à natureza. Estas duas concepçôes têm sido consideradas antagônicas, a primeira, sujeita ao jugo positivista, a segunda, liberta dele, e qualquer delas reivindicando o monopolio do conhecimento científico-social. Apresentarei adiante uma interpretação diferente, mas para ja caracterizarei sucintamente cada uma destas variantes.

A primeira variante - cujo compromisso epistemológico está bem simbolizado no nome de "física social" com que inicialmente se designaram os estudos científicos da sociedade - parte do pressuposto que as ciências naturais são uma aplicação ou concretização de um modelo de conhecimento universalmente válido $e$, de resto, o único válido.

Portanto, por maiores que sejam as diferenças entre os fenômenos naturais e os fenômenos sociais é sempre possível estudar os últimos como se fossem os primeiros. Reconhece-se que essas diferenças atuam contra os fenômenos sociais, ou seja, tornam mais difícil o cumprimento do cânone metodologico e menos rigoroso o conhecimento a que se chega, mas não há diferenças qualitativas entre 0 processo científico neste domínio e o que preside ao estudo dos fenômenos naturais. Para estudar os fenômenos sociais como se fossem fenômenos naturais, ou seja, para conceber os fatos sociais, como coisas, como pretendia Durkheim ${ }^{18}$, o fundador da sociologia acadêmica, é necessário reduzir os fatos sociais ds suas dimensões extermas, observáveis e mensuráveis. As causas do aumento da taxa de suicídio na Europa do virar do seculo não são procuradas nos motivos invocados pelos suicidas e deixados em cartas, como é costume, mas antes a partir da verificação de regularidades em função de condições tais como o sexo, o estado civil, a existência ou não de filhos, a religião dos suicidas 19 .

Porque essa redução nem sempre é fácil e nem sempre se consegue sem distorcer grosseiramente os fatos ou sem os reduzir à quase irrelevância, as ciências sociais têm um longo caminho a percorrer

15 Bacon, ob. cit.

16 Vico, Scienza Nuova, in Opere. Milēo Riccardi, 1953.

17 Montesquieu, L'Esprit des Lois. Paris, Les Belles-Lettres, 1950.

18 E. Durkheim, As Regras do Método Sociológico. Lisboa, Presença, 1980.

19 E, Durkheim, O Surcidio. Lisboa, Presenca, 1973. 
no sentido de se compatibilizarem com os critérios de cientificidade das ciências naturais. Os obstáculos são enormes mas não são insuperáveis. Ernest Nagel, em The Structure of Science, simboliza bem o esforço desenvolvido nesta variante para identificar os obstáculos e apontar as vias da sua superação. Eis alguns dos principais obstáculos: as ciências sociais não dispõem de teorias explicativas que thes permitam abstrair do real para depois buscar nele, de modo metodologicamente controlado, a prova adequada; as ciências sociais não podem estabelecer leis universais porque os fenômenos sociais são historicamente condicionados e culturalmente determinados; as ciências sociais não podem produzir previsões fiáveis porque os seres humanos modificam o seu comportamento em função do conhecimento que sobre ele se adquire; os fenômenos sociais são de natureza subjetiva e como tal ño se deixam captar pela objetividade do comportamento; as ciências sociais não são objetivas porque o cientista social não pode libertar-se, no ato de observação, dos valores que informam a sua prática em geral e, portanto, também a sua prática de cientista 20 .

Em relação a cada um destes obstáculos, Nagel tenta demonstrar que a oposição entre as ciências sociais e as ciências naturais não e tão linear quanto se julga e que, na medida em que há diferenças, elas são superáveis ou negligenciáveis. Reconhece, no entanto, que a superação dos obstáculos nem sempre é fácil e que essa é a razão principal do atraso das ciências sociais em relação às ciências naturais. A idéia do atraso das ciências sociais é a idéia central da argumentação metodológica nesta variante, e, com ela, a idéia de que esse atraso, com tempo e dinheiro, poderá vir a ser reduzido ou mesmo eliminado.

$\mathrm{Na}$ teoria das revoluçoes científicas de Thomas Kuhn o atraso das ciências sociais é dado pelo caráter pré-paradigmático destas ciências, ao contrário das ciências naturais, essas sim, paradigmáticas. Enquanto, nas ciencias naturais, o desenvolvimento do conhecimento tornou possível a formulaçâo de um conjunto de princípios e de teorias sobre a estrutura da matéria que são aceites sem discussão por toda a comunidade cientifica, conjunto esse que designa por paradigma, nas ciências sociais não há consenso paradigmático, pelo que o debate tende a atravessar verticalmente toda a espessura do conhecimento adquirido. $\mathrm{O}$ esforço e o desperdício que isso acarreta é simultaneamente causa e efeito do atraso das ciências sociais.

A segunda vertente reivindica para as ciências sociais um estatuto metodológico próprio. Os obstáculos que há pouco enunciei são, segundo esta vertente, intransponiveis. Para alguns, é a própria idéia de ciência da sociedade que está em causa, para outros trata-se tão-só de empreender uma ciência diferente. $\mathrm{O}$ argumento fundamental é que a ação humana é radicalmente subje tiva. O comportamento humano. ao contrário dos fenômenos naturais, não pode ser descrito e muito menos explicado com base nas suas caracteristicas exteriores e objetiváveis, uma vez que o mesmo ato externo pode corresponder a sentidos de ação muito diferentes. A ciência social será sempre uma ciência subjetiva e não objetiva como as ciências naturais; tem de compreender os fenómenos sociais a partir das atitudes mentais e do sentido que os agentes conferem às suas ações, para o que é necessário utilizar métodos de investigação e mesmo criterios epistemológicos diferentes dos correntes nas ciências naturais, métodos qualitativos em vez de quantitativos, com vista à obtenção de um conhecimento intersubjetivo, descritivo e compreensivo, em vez de um conhecimento objetivo, explicativo e nomotético.

Esta concepção de ciência social reconhece-se numa postura antipositivista e assenta na tradição filosofica da fenomenologia e nela convergem diferentes variantes, desde as mais

20 Ernest Nagel, The Structure of Science. Problems in the Logic of Scientific Explanation. Nova Iorque, Harcourt, Brace \& World, 1961, p. 447 e segs. 
moderadas (como a de Max Weber) 21 ate às mais extremistas (como a de Peter Winch) 22 . Contudo, numa reflexão mais aprofundada, esta concepção, tal como tem vindo a ser elaborada, revela-se mais subsidiaria do modelo de racionalidade das ciências naturaís do que parece. Partilha com este modelo a distinção natureza/ser humano e tal como ele tem da natureza uma visão mecanicista à qual contrapõe, com evidéncia esperada, a especificidade do ser humano. A esta distinçao, primordial na revolução cientifica do seculo XVI, vão-se sobrepor nos séculos seguintes outras, tal como a distinção natureza/ cultura e a distinção ser humano/ animal, para no século XVIII se poder celebrair o caráter único de ser humano. A fronteira que então se estabelece entre 0 estudo do ser humano e o estudo da natureza não deixa de ser prisioneira do reconhecimento da prioridade coǵnitiva das ciências naturais, pois, se; por um lado, se recusam os condicionantes biológicos do comportamento humano, pelo outro usam-se argumentos biológicos para fixar a especificidade do ser humano. Pode, pois, concluir-se que ambas as concepções de ciência social a que aludi pertencem ao paradigma da ciência modema, ainda que a concepção mencionada em segundo lugar represente, dentro deste paradigma, um sinal de crise e contenhà alguns dos componentes da transição para um outro paradigma cientrfico.

\section{A Crise do Paradigma Dominante}

São hoje muitos e fortes os sinais de que o modelo de racionalidade científica que acabo de descrever em alguns dos seus traços principais atravessa uma profunda crise. Defenderei nesta seção: primeiro, que essa crise é não só profunda como irreversível; segundo, que estamos a viver um período de revolução científica que se iniciou com Einstein e a mecânica quântica e ñ̃o se sabe ainda quando acabara; terceiro, que os sinais nos permitem tão-só especular acerca.do paradigma que emergirá deste perfodo revolucionário mas que, desde já, se pode afirmar com segurança que colapsarão as distinções básicas em que assenta o paradigma dominante e a que aludi na seção precedente.

A crise do paradigma dominante é o . resultado interativo de uma pluralidade de condições. Distingo entre condiçōes sociais e condições teóricas. Darei mais atenção d̀s condiçōes teoricas e por elas começo. A primeira observação, que . não e tão trivial quanto parece, e que a identificação dos limites, das insuficiências estruturais do paradigma científico moderno é o resultado do grande avanço no conhecimento que ele propiciou. $O$ aprofundamento do conhecimento permitiu ver a fragilidade dos pilares em que se funda.

Einstein constitui o primeiro rombo no paradigma da ciência moderna, um rombo, alias, mais importante do que o que Einstein foi subjetivamente capaz de admitir. Um dos pensamentos mais profundos de Einstein é o da relatividade da simultaneidade. Einstein distingue entre a simultaneidade de acontecimentos presentes no mesmo lugar e a simultaneidade de acontecimentos distantes, em particular de acontecimentos separados por distâncias astronômicas. Em relação a estes últimos, o problema logico a resolver é o seguinte: como é que o observador estabelece a ordem temporal de acontecimentos no espaço? Certamente por medições da velocidade da luz, partindo do pressuposto, que é fundamental à teoria de Einstein, que não há na natureza velocidade superior à da luz. No entanto, ao medir a velocidade numa direção única (de A a B), Einstein defronta-se com um círculo vicioso: a fim de determinar a simultaneidade dos acontecimentos distantes é nécessário conhecer a velocidade; mas para medir a velocidade é necessário conhecer a simultaneidade dos acontecimentos. Com um golpe de genio, Einstein rompe com este círculo, demonstrando que a simultaneidade de-acontecimentos distantes não pode ser verificada, pode tão-só ser.definida. E, portanto, arbitrária e daí que, como salienta
A crise do paradigma dominante é 0 resultado interativo de uma pluralidade de condiçöes. Distingo entre condiçōes sociais e condições teóricas. (...) a identificação dos limites, das insuficiências estruturais do paradigma cientffico moderno é o resul tado do grande avanço no conhecimento que ele propiciou. 0 aprofundamento do conhecimento permitiu ver a fragilidade dos pilares em que se funda.

21 Max Weber, Methodologischen Schriften. Frankfurt, Fischer, 1968.

22 Peter Winch; The Idea of a Social Science and its Relation to Philosophy. Londres, Routledge e Kegan Paul, 1970. 
Reichenbach, quando fazemos medições não pode haver contradições nos resultados uma vez que estes nos devolverão a simultaneidade que nós introduzimos por definição no sistema de medição 23 . Esta teoria veio revolucionar as nossas concepçōes de espaço e de tempo. Não havendo simultaneidade universal, o tempo e o espaço absolutos de Newton deixam de existir. Dois acontecimentos simultâneos num sistema de referência não são simultâneos noutro sistema de referência. As le is da física e da geometria assentam em medições locais. "Os instrumentos de medida, sejam relógios ou metros, não têm magnitudes independentes, ajustam-se ao campo métrico do espaço, a estrutura do qual se manifesta mais claramente nos raios de luz" 24.

O caráter local das mediçôes e, portanto. do rigor do conhecimento que com base nelas se obtém, vai inspirar o surgimento da segunda condição teórica da crise do paradigma dominante, a mecânica quântica. Se Einstein relativizou o rigor das leis de Newton no domínio da astrofísica, a mecânica quântica fề-lo no domínio da microfísica. Heisenberg e Bohr demonstram que não é possível observar ou medir um objeto sem interferir nele, sem o alterar, e a tal ponto que o objeto que sai de um processo de medição não é o mesmo que lá entrou. Como ilustra Wigner, "a medição da curvatura do espaço causada por uma partícula não pode ser levada a cabo sem criar novos campos que são bilhões de vezes maiores que o campo sob investigação" 25 . A idéia de que não conhecemos do real senão o que nele introduzimos, ou seja, que não conhecemos do real senão a nossa intervenção nele, está bem expressa no princípio da incerteza de Heisenberg: não se podem reduzir simultaneamente os erros da medição da velocidade e da posição das partículas; o que for feito para reduzir o erro de uma das medições aumenta o erro da outra 26 . Este princípio, e, portanto, a demonstração da interferência estrutural do sujeito no obje to observado. tem implicações de vulto. Por um lado, sendo estruturalmente limitado o rigor do nosso conhecimento, só podemos aspirar a resultados aproximados e por isso as leis da física são tão-só probabilisticas. Por outro lado, a hipótese do determinismo mecanicista é inviabilizada uma vez que a totalidade do real não se reduz à soma das partes em que a dividimos para observar e medir. Por último, a distinção sujeito/ obje to é muito mais complexa do que à primeira vista pode parecer. A distinção perde os seus contornos dicotômicos e assume a forma de um continuum. $O$ rigor da medição posto em causa pela mecânica quântica será ainda mais profundamente abalado se se questionar o rigor do veículo formal em que a medição é expressa, ou seja, o rigor da matemática. $E$ isso o que sucede com as investigações de Gödel e que por essa razão considero serem a terceira condição da crise do paradigma. $O$ teorema da incompletude (ou do não-completamento) e os teoremas sobre a impossibilidade, em certas circunstâncias, de encontrar dentro de um dado sistema formal a prova da sua consistência vieram mostrar que, mesmo seguindo à risca as regras da lógica matematica, é possível formular proposições indecidíveis, proposições que se não podem demonstrar nem refutar, sendo que uma dessas proposições é precisamente a que postula o caráter não-contraditório do sistema 27 . Se as

$23 H$. Reichenbach, From Copernicus to Einstein, Nova Iorque, Dover Publications, 1970, p. 60.

24 H. Reichenbach, ob. cit., p. 68.

25 E. Wigner, ob. cit, p. 7.

26 W. Heisenberg, A Imagem da Natureza na Física Moderna. Lisboa, Livros do Brasil, s. d.; W. Heisenberg, Physics and Beyond. Londres, Allen and Unwin, 1971.

27 O impacto dos teoremas de Gödel na filosofia da ciência tem sido diversamente avaliado. Cf., por exemplo, J. Ladrière, "Les Limites de la Formalization", in J. Piaget (org.), Logique et Connaissance Scientifique. Paris, Gallimard, 1967, p. 312 e segs.; R. Jones, Physics as Metaphor. Nova Iorque, New American Library, 1982, p. 158; J. Parain-Vial, Philosophie des Sciences de la Nature. Tendances Nouvelles. Paris, Klincksieck, 1983, p. 52 e segs.; R. Thom, Parábolas e Catástrofes, Lisboa, D. Quixote, 1985, p. 36; J. Briggs e F. D. Peat, Looking Glass Universe. The Emerging Science of Wholeness. Londres, Fontana, 1985, p. 22. 
leis da natureza fundamentam o seu rigor no rigor das formalizações matemáticas em que se expressam, as investigaçōes de Gödel vêm demonstrar que o rigor da matemática carece ele próprio de fundamento. A partir daqui é possivel não sర questionar o rigor da matematica como também redefini-lo enquanto forma de rigor que se opoe a outras formas de rigor alternativo, uma forma de rigor cujas condiçóes de êxito na ciência moderna não podem continuar a ser concebidas como naturais e óbvias. A própria filosofia da matematica, sobretudo a que incide sobre a experiência matemática, tem vindo a problematizar criativamente estes temas e reconhece hoje que o rigor matemático, como qualquer outra forma de rigor, assenta num critério de seletividade e que, como tal, tem um lado construtivo e um lado destrutivo. A quarta condição teórica da crise do paradigma newtoniano é constituída pelos avanços do conhecimento nos domínios da microfísica, da química e da biologia nos últimos vinte anos. A título de exemplo, menciono as investigaçōes do físico-químico llya. Prigogine. A teoria das estruturas dissipativas e o princípio da "ordem através de flutuaçð̄es" estabelecem que em sistemas abertos, ou seja, em sistemas que funcionam nas margens da estabilidade, a evolução explica-se por flutuaçōes de energia que em determinados momentos, nunca inteiramente previsíveis, desencadeiam espontaneamente reaçōes que, por via de mecanismos nao-lineares, pressionam o sistema para além de um limite máximo de instabilidade e o conduzem a um novo estado macroscópico. Esta transformação irreversível e termodinâmica e o resultado da interação de processos microscópicos segundo uma lógica de auto-organização numa situação de não-equilíbrio. $A$ situação de bifurcação, ou seja, o ponto crítico em que a mínima flutuação de energia pode conduzir a um novo estado, representa a potencialidade do sistema em ser atrardo para um novo estado de menor entropia. Deste modo a irreversibilidade nos sistemas abertos significa que estes são produto da sua história 28.

A importância desta teoria está na nova concepção da matéria e da natureza que propõe, uma concepção dificilmente compaginada com a que herdamos da física clássica. Em vez da eternidade, a historia; em vez do determinismo, a imprevisibilidade; em vez do mecanicismo, a interpenetração, a espontaneidade e a auto-organização; em vez da reversibilidade, a irreversibilidade e a evolução; em vez da ordem, a desordem; em vez da necessidade, a criatividade e 0 acidente. A teoria de Prigogine recupera inclusivamente conceitos aristotélicos tais como os conceitos de potencialidade e virtualidade que a revolução científica do século XVI parecia ter atirado definitivamente para o lixo da história.

Mas a importância maior desta teoria está em que ela não é um fenómeno isolado. Faz parte de um movimento convergente, pujante sobretudo a partir da ulltima decada, que atravessa as várias ciências da natureza e até as . ciências sociais, um movimento de vocação transdisciplinar que Jantsch designa por paradigma da auto-organização e que tem afloraçōes. entre outras, na teoria de Prigogine, na sinergética de Haken 29 , no conceito de hiperciclo e na teoria da origem da vida de Eigen 30 , no conceito de autopoiesis de Maturana e Varela 31 , na teoria das

28 I. Prigogine e I. Stengers, La Nouvelle Alliance. Metamorphose de la Science. Paris, Gallimard, 1979; I. Prigogine, From Being to Becoming. S. Francisco, Freeman, 1980; I. Prigogine, "Time, Irreversibility and Randomness", in E. Jantsch (org.), The Evolutionary Vision. Boulder, Westview Press, p. 73 e segs.

29 H. Hanjen, Synergetics: an introduction. Heidelberg, Springer 1977; H. Haken, "Synergetics An Interdisciplinary A pproach to Phenomena of Self-Organization", Geoforum 16 (1985), 205.

30 M. Eigen e P. Schuster, The Hypercycle: a principle of natural self-organization. Heidelberg, Springer, 1979.

31 H. R. Maturana e F. J. Varela, De Maquinas y Sexes Vivos. Santiago do Chile, Editorial Universitdria, 1973;H. R. Maturana e J. F. Varela, Autopoietic Systems. Urbana, Biological Computer Laboratory University of Ilinois, 1975. Cf., tambem, F. Benseler, P. Hejl e W. Koch (orgs.), Autopoiesis. Communication and Society. The Theory of Autopoietic Systems in the Social Sciences. Frankfurt, Campus, 1980. 
Mas acima de tudo, a simplicidade das leis constitui uma simplificação arbitrária da realidade que nos confina a um horizonte mínimo para além do qual outros conhecimentos da natureza, provavelmente mais ricos e com mais interesse humano. ficam por conhecer. $\mathrm{Na}$ biologia, onde as interações entre fenômenose formas de auto-organização em totalidades

não-mecânicas são mais visíveis, mas também nas demais cièncias, a noção de lei tem vindo a ser parcial e sucessivamente substituída pelas noçôes de sistema, de estrutura, de modelo e, por último, pela noção de processo. catástrofes de Thom 32 , na teoria da evolução de Jantsch ${ }^{33}$, na teoria da "ordem implicada" de David Bohm ${ }^{34}$ ou na teoria da matriz-S de Geoffrey Chew e na filosofia do "bootstrap" que the subjaz 35 . Este movimento cientifico e as demais inovações teoricas que atrás defini como outras tantas condições teóricas da crise do paradigma dominante têm vindo a propiciar uma profunda reflexão epistemológica sobre o conhecimento científico, uma reflexão de tal modo rica e diversificada que. melhor do que qualquer outra circunstância, caracteriza exemplarmente a situação intelectual do tempo presente. Esta reflexão apresenta duas facetas sociologicas importantes. Em primeiro lugar, a reflexão é levada a cabo predominantemente pelo próprios cientistas, por cientistas que adquiriram uma competência $\mathrm{e}$ um interesse filosoficos para problematizar a sua prática científica. Não é arriscado dizer que nunca houve tantos cientistas-filosofos como atualmente, e isso não se deve a uma evolução arbitrária do interesse intelectual. Depois da euforia cientista do século XIX e da consequente aversão à reflexão filosófica. bem simbolizada pelo positivismo, chegamos a finais do século $\mathrm{XX}$ possuídos pelo desejo quase desesperado de complementarmos o conhecimento das coisas com o conhecimento do conhecimento das coisas, isto é, com o conhecimento de nós próprios. A segunda face ta desta reflexão é que ela abrange questōes que antes eram deixadas aos sociologos. A análise das condições sociais, dos contex tos culturais, dos modelos organizacionais da investigação cientifica, antes acantonada no campo separado e estanque da sociologia da ciência, passou a ocupar papel de relevo na reflexđ̃o epistemológica.

Do conteudo desta reflexão respigarei, a título ilustrativo, alguns dos temas principais. Em primeiro lugar, são questionados o conceito de lei e o conceito de causalidade que lhe está associado. A formulação das leis da natureza funda-se na ideia de que os fenômenos observados independem de tudo exce to de um conjunto razoavelmente pequeno de condições (as condiçбes iniciais) cuja interferência é observada e medida. Esta idéia, reconhece-se hoje, obriga a separações grosseiras entre os fenômenos, separações que, aliás, são sempre provisórias e precárias uma vez que a verificação da não-interferência de certos fatores é sempre produto de um conhecimento imperfeito, por mais perfeito que seja. As leis têm assim um caráter probabilistico, aproximativo e provisório, bem expresso no princípio da falsificabilidade de Popper. Mas acima de tudo, a simplicidade das leis constitui uma simplificação arbitrária da realidade que nos confina a um horizonte mínimo para além do qual outros conhecimentos da natureza, provavelmente mais ricos e com mais interesse humano, ficam por conhecer. $\mathrm{Na}$ biologia, onde as interações entre fenômenos e formas de auto-organização em totalidades não-mecânicas sẫo mais visiveis, mas tambem nas demais ciências, a noção de lei tem vindo a ser parcial e sucessivamente substituida pelas noções de sistema, de estrutura, de modelo e, por último, pela noção de processo. $O$ declínio da hegemonia da legalidade $e$ concomitante do declínio da hegemonia da causalidade. $O$ questionamento da causalidade nos tempos modernos vem de longe, pelo menos desde David Hume e do positivismo lógico. A reflexao crítica tem incidido tanto no problema ontológico da causalidade (quais as características do nexo causal?; esse nexo existe na realidade?) como sobre o problema metodologico da causalidade (quais os critérios de causalidade?; como

32 R. Thom, ob. cit., p. 85 e segs.

$33 E$. Jantsch. The Self-Organizing Universe : scientific and human implications of the emerging paradigm of evolution. Oxford, Pergamon, 1980; E. Jantsch. "Unifying Principles of Evolution", E. Jantsch (org.), The Evolutionary Vision, cit., p. 83 e segs.

34 D. Bohm, Wholeness and the Implicate Order. Londres, Ark Paperbacks, 1984.

35 G. Chew, "Bootstrap: a scientific idea?", Science 161 (1968), p. 762 e segs; G. Chew, "Hardon bootstrap: triumph or frustration?", Physics Today, 23 (1970) p. 23 e segs; F. Capra, "Quark physics without quarks: a review of recent developments in S-matrix theory", American Journal of Physics, 47 (1979), p. 11 e segs. 
reconhecer um nexo causal ou testar uma hipotese causal?). Hoje, a relativização do conceito de causa parte sobretudo do reconhecimento de que o lugar central que ele tem ocupado na ciência moderna se explica menos por razões ontológicas ou metodologicas do que por razões pragmáticas. 0 conceito de causalidade adequa-se bem a uma ciência que visa intervir no real e que mede o seu êxito pelo âmbito dessa intervenção. Afinal, causa é tudo aquilo sobre que se pode agir. Mesmo os defensores da causalidade, como Mario Bunge, reconhecem que ela é apenas uma das formas do determinismo e que por isso tem um lugar limitado, ainda que insubstituível, no conhecimento científico $^{36}$. A verdade é que, sob a égide da biologia e também da microfísica, o causalismo, enquanto categoria de inteligibilidade do real, tem vindo a perder terreno em favor do finalismo.

O segundo grande tema de reflexao epistemológica versa mais sobre o conteúdo do conhecimento científico do que sobre a sua forma. Sendo um conhecimento mínimo que fecha as portas a muitos outros saberes sobre o mundo, o conhecimento científico moderno é um conhecimento desencantado e triste que transforma a natureza num autômato, ou, como diz Prigogine, num interlocutor terrivelmente estúpido 37 . Este aviltamento da natureza acaba por aviltar o proprio cientista na medida em que reduz o suposto diálogo experimental ao exercício de uma prepotência sobre a natureza. $O$ rigor científico, porque fundado no rigor matemático, é um rigor que quantifica e que, ao quantificar, desqualifica, um rigor que, ao objetivar os fenômenos, os objetualiza e os degrada, que, ao caracterizar os fenômenos, os caricaturiza. E, em suma e finalmente, uma forma de rigor que, ao afirmar a personalidade do cientista, destrói a personalidade da natureza. Nestes termos, o conhecimento ganha em rigor o que perde em riqueza e a retumbância dos êxitos da intervenção tecnológica esconde os limites da nossa compreensão do mundo e reprime a pergunta pelo valor humano do afã científico assim concebido. Esta pergunta está, no entanto, inscrita na própria relação sujeito/objeto que preside à ciência moderna, uma relação que interioriza o sujeito à custa da exteriorização do objeto, tornando-os estanques e incomunicáveis.

Os limites deste tipo de conhecimento são, assim, qualitativos, não são superáveis com maiores quantidades de investigação ou maior precisão dos instrumentos. Aliás, a própria precisão quantitativa do conhecimento é estruturalmente limitada. Por exemplo, no domínio das teorias da informação o teorema de Brillouin demonstra que a informação não é gratuita 38 . Qualquer observação efetuada sobre um sistema físico aumenta a entropia do sistema no laboratório. $\mathrm{O}$ rendimento de uma dada experiência deve assim ser definido pela relação entre a informação obtida e o aumento concomitante da entropia. Ora, segundo Brillouin, esse rendimento é sempre inferior à unidade e só em casos raros é próximo dela. Nestes termos, a experiência rigorosa é irrealizável pois que exigiria um dispêndio infinito de atividades humanas. Por último, a precisão é limitada porque, se é verdade que o conhecimento só sabe avançar pela via da progressiva parcelização do objeto, bem representada nas crescentes especializações da ciência, $e$ exatamente por essa via que melhor se confirma a irredutibilidade das totalidades orgânicas ou inorgânicas às

36 M. Bunge, Causality and Modern Science. Nova Iorque, Dover Publications, $3^{a}$ edição, 1979 , p. 353: "The causal principle is, in short, neither a panacea nor a myth; it is a general hypothesis subsumed under the universal principle of determinacy, and having an approximate validity in its proper domain". Em Portugal é justo salientar neste domínio a notável obra teórica de Armando Castro. Cf. Teoria do Conhecimento Científico, vols. I-IV, Porto Limiar, 1975, 1978, 1980, 1982; vol. V, Porto, Afrontamento, 1987.

37 I. Prigogine e I. Stengers, ob. cit., p. 13.

38 L. Brillouin, La Science et la Theorie de I'Information. Paris, Masson, 1959. Cf, também, Parain-Vial, ob. cit., p. 122 e segs. 
partes que as constituem e, portanto, $o$ caráter distorsivo do conhecimento centrado na observação destas últimas. Os fatos observados têm vindo a escapar ao regime de isolamento prisional a que a ciência os sujeita. Os objetos têm fronteiras cada vez menos definidas; são constituídos por aneis que se entrecruzam em teias complexas com os dos restantes objetos, a tal ponto que os objetos em si são menos reais que as relações entre eles.

Ficou dito no início desta parte que a crise do paradigma da ciência moderna se explica por condições teóricas, que acabei ilustrativamente de apontar, e por condições sociais. Estas últimas não podem ter aqui tratamento detalhado ${ }^{39}$. Referirei tão-só que, quaisquer que sejam os limites estruturais de rigor cientifico. não restam dúvidas que o que a ciência ganhou em rigor nos últimos quarenta ou cinqüenta anos perdeu em capacidade de auto-regulação. As idéias da autonomia da ciência e do desinteresse do conhecimento científico, que durante muito tempo constituiram a ideologia espontânea dos cientistas, colapsaram perante o fenômeno global da industrialização da ciência a partir sobretudo das décadas de trinta e quarenta. Tanto nas sociedades capitalistas como nas sociedades socialistas de Estado do leste europeu, a industrialização da ciência acarretou o compromisso desta com os centros de poder econômico, social e político, os

As idéias da autonomia da ciência e do desinteresse do conhecimento científico, que durante muito tempo constituíram a ideologia espontânea dos cientistas, colapsaram perante $o$ fenômeno global da industrializaçâo da ciência a partir sobretudo das décadas de trinta $e$ quarenta. quais passaram a ter um papel decisivo na definição das prioridades científicas.

A industrialização da ciência aplicações da ciência como ao nível da organização da investigação científica. Quanto às aplicações, as bombas de Hiroshima e Nagasaki foram um sinal trágico, a princípio visto como acidental e fortuito, mas hoje, perante a catástrofe ecológica e o perigo do holocausto nuclear, cada vez mais visto como manifestação de um modo de produção da ciência inclinado a transformar acidentes em ocorrencias sistematicas. manifestou-se tanto ao nivel das
"A ciência e a tecnologia têm vindo a revelar-se as duas faces de um processo historico em que os interesses militares e os interesses econômicos vão convergindo até quase à indistinção" 40 . No dominio da organização do trabalho científico, a industrialização da ciência produziu dois efeitos principais. Por um lado, a comunidade científica estratificou-se, as relações de poder entre cientistas tornaram-se mais autoritárias e desiguais e a esmagadora maioria dos cientistas foi submetida a um processo de proletarização no interior dos laboratórios e dos centros de investigação. Por outro lado, a investigação capital-in tensiva (assente em instrumentos caros e raros) tornou impossivel o livre acesso ao equipamento, o que contribuiu para o aprofundamento do fosso, em termos de desenvolvimento cientrfico e tecnológico, entre os países centrais e os países periféricos.

Pautada pelas condiçôes teóricas e sociais que acabei de referir, a crise do paradigma da ciência moderna não constitui um pântano cinzento de ceticismo ou de irracionalismo. É antes o retrato de uma familia intelectual numerosa e instável, mas também criativa e fascinante, no momento de se despedir, com alguma dor, dos lugares conceituais, teóricos c epistemológicos, ancestrais e f́ntimos, mas nâo mais convincentes e securizantes, uma despedida em busca de uma vida melhor a caminho doutras paragens onde $o$ otimismo seja mais fundado e a racionalidade mais plural e onde finalmente o conhecimento volte a ser uma aventura encantada. A caracterização da crise do paradigma dominante traz consigo o perfil do paradigma emergente. E esse o perfil que procurarei desenhar a seguir.

\section{O Paradigma Emergente}

A configuração do paradigma que se anuncia no horizonte só pode obter-se por via especulativa. Uma especulação fundada nos sinais que a crise do paradigma atual emite mas nunca por

\section{Sobre este tema cf. Boaventura de Sousa Santos, "Da Sociologia da Ciência à Polttica Cientifica", Revista Crítica de Ciências Sociais, 1 (1978), p. 11 e segs.}

Boaventura de Sousa Santos, ob. cit., p. 26. 
eles determinada. Aliás, como diz René Poirier e antes dele disseram Hegel e Heidegger, "a coerência global das nossas verdades físicas e metafísicas so se conhece retrospectivamente" 41 . Por isso, ao falarmos do futuro, mesmo que seja de um futuro que já nos sentimos a percorrer, $o$ que dele dissermos é sempre o produto de uma sintese pessoal embebida na imaginação, no meu caso na imaginação sociológica. Não espanta, pois, que ainda que com alguns pontos de convergência, sejam diferentes as sinteses até agora apresentadas. Ilya Prigogine, por exemplo, fala da nova aliança e da metamorfose da ciência 42 . Fritjof Capra fala da "nova física" e do Taoísmo da física 43 , Eugene Wigner de "mudanças do segundo tipo"44, Erich Jantsch do paradigma da auto. organização 45 , Daniel Bell da sociedade pós-industrial 46 , Habermas da sociedade comunicativa 47 . Eu falarei, por agora, do paradigma de um conhecimento prudente para uma vida decente. Com esta designação quero significar que a natureza da revolução cientifica que atravessamos é estruturalmente diferente da que ocorreu no século XVI. Sendo uma revolução cientrfica que ocorre numa sociedade ela própria revolucionada pela ciência, o paradigma a emergir dela não pode ser apenas um paradigma científico (o paradigma de um conhecimento prudente), tem de ser também um paradigma social (o paradigma de uma vida decente). Apresentarei o paradigma emergente através de um conjunto de teses seguidas de justificação.

\section{Todo o conhecimento}

cientifico-natural é científico-social

A distinção dicotômica entre ciências naturais e ciências sociais começa a deixar de ter sentido e utilidade. Esta distinção assenta numa concepção mecanicista da matéria e da natureza a que contrapõe, com pressuposta evidência, os conceitos de ser humano, cultura e sociedade. Os avanços recentes da física e da biologia põem em causa a distinção entre $o$ orgânico $\mathrm{e} O$ inorgânico, entre seres vivos e matéria inerte e mesmo entre o humano e o não-humano. As caracterŕsticas da auto-organização, do metabolismo e da auto-reprodução, antes consideradas especificas dos seres vivos, são hoje atribuidas aos sistemas pré-celulares de moléculas. E quer num quer noutros reconhecem-se propriedades e comportamentos antes considerados especificos dos seres humanos e das relações sociais. A teoria das estruturas dissipativas de Prigogine, ou a teoria sinergética de Haken já citadas, mas também a teoria da ordem implicada de David Bohm, a teoria da matriz-S de Geoffrey Chew e a filosofia do "bootstrap" que lhe subjaz e ainda a teoria do encontro entre a física contemporânea e o misticismo oriental de Fritjof Capra, todas elas de vocação holistica e algumas especificamente orientadas para superar as inconsistências entre a mecânica quântica $e$ a teoria da relatividade de Einstein, todas estas teorias introduzem na matéria os conceitos de historicidade e de processo, de liberdade, de auto-determinação e até de consciência que antes o homem e a mulher tinham reservado para si. E como se o homem e a mulher se tivessem lançado na aventura de conhecer os objetos mais distantes e diferentes de si próprios, para, uma vez ar chegados, se descobrirem refletidos como num espelho. Já no princípio da década de sessenta e extrapolando a partir da mecânica quântica, Eugene Wigner considerava que o inanimado não era uma qualidade diferente mas apenas um casolimite, que a distinção corpo/alma deixara de ter sentido e que a física e a psicologia acabariam por se fundir numa única
A distinção dicotômica entre ciências naturais e ciências sociais começa a deixar de ter sentido e utilidade. Esta distinção assenta numa concepção mecanicista da matéria e da natureza a que contrapõe, com pressuposta evidência, os conceitos de ser humano, cultura e sociedade.

41 R. Poirier, prefacio a Parain-Vial, ob. cit., p. 10.

42 I. Prigogine, obs. cits.

43 F. Capra, The Tao of Physics, Nova Iorque, Bantam Books, (1976), 1984; F. Capra, The Turning Point. Nova Iorque, Bantam Books, 1983.

44 E. Wigner, ob. cit., p. 215 e segs.

45 E. Jantsch, obs. cits.

46 D. Bell, The Coming Crisis of Post-Industrial Society. Nova Iorque, Basic Books, 1976.

47 J. Habermas, Theorie des Kommunikativen Handelns, 2 vols. Frankfut, Suhrkamp, 1982. 
ciência 48 . Hoje é possível ir muito além da mecânica quântica. Enquanto esta introduziu a consciência no ato do conhecimento, nós temos hoje de a introduzir no próprio objeto do conhecimento, sabendo que, com isso, a distinção sujeito/objeto sofrerá uma transformação radical. Num certo regresso ao pan-psiquismo leibniziano, começa hoje a reconhecer-se uma dimensão psíquica na natureza, "a mente mais ampla" de que fala Bateson, da qual a mente humana é apenas uma parte, uma mente imanente ao sistema social global e à ecologia planetária que alguns chamam Deus 49 . Geoffrey Chew postula a existência de consciência na natureza como um elemento necessário à autoconsistência desta última $\mathrm{e}$, se assim for, as futuras teorias da matéria terão de incluir o estudo da consciência humana. Convergentemente, assiste-se a um renovado in teresse pelo "inconsciente cole tivo", imanente à humanidade no seu todo, de Jung. Aliás, Capra pretende ver as idéias de Jung - sobretudo a idéia da sincronicidade para explicar a relação entre a realidade exterior e a realidade interior - confirmadas pelos recentes conceitos de interaçōes locais e nãolocais na física das partículas 50 . Tal como na sincronia jungiana, as interações nđo-locais são instantâneas e não podem ser previstas em termos matemáticos precisos. Não são, pois, produzidas por causas locais e, quando muito, poder-se-á falar da causalidade estatística. Capra vê em Jung uma das alternativas teóricas às concepções mecanicistas de Freud e Bateson afirma que enquanto Freud ampliou o conceito de mente para dentro (permitindo-nos abranger $o$ subsconsciente e o inconsciente) é necessário agora ampliá-lo para fora (reconhecendo a existência de fenômenos mentais para além dos individuais e humanos). Semelhantemente, a teoria da ordem implicada, que, segundo o seu autor, David Bohm, pode constituir uma base comum tanto à teoria quântica como à teoria da relatividade, concebe a consciência e a matéria como interdependentes sem, no entanto, estarem ligadas por nexo de causalidade. São antes duas projeções, mutuamente envolventes, de uma realidade mais alta que não é nem matéria nem consciência. 0 conhecimento do paradigma emergente tende assim a ser um conhecimento nao. dualista, um conhecimento que se funda na superação das distinções tão familiares e óbvias que até há pouco considerávamos insubstituiveis, tais como natureza/ cultura, natural/artificial, vivo/inanimado, mente/matéria, observador/observado, subjetivo/objetivo, coletivo/individual, animal/pessoa. Este relativo colapso das distinções dicotômicas repercute-se nas disciplinas cientrficas que sobre elas se fundaram. Aliás, sempre houve ciências que se reconheceram mal nestas distinções e tanto que se tiveram de fraturar internamente para se lhes adequarem minimamente. Refiro-me à antropologia, à geografia e também à psicologia. Condensaram-se nelas privilegiadamente as contradiçōes da separação ciências naturais/ciências sociais. Daí que, num perrodo de transição entre paradigmas, seja particularmente importante, do ponto de vista epistemológico, observar o que se passa nessas ciências.

Não basta, porém, apontar a tendência para a superação da distinção entre ciências naturais e ciências sociais, é preciso conhecer o sentido e conteúdo dessa superação. Recorrendo de novo à física, trata-se de saber qual será o "parâmetro de ordem", segundo Haken, ou o "atractor", segundo Prigogine, dessa superação, se as ciências naturais, se as ciências sociais. Precisamente porque vivemos um estado de turbulência, as vibrações do novo paradigma repercutem-se desigualmente nas várias regiões do paradigma vigente e por isso os sinais do futuro são ambíguos. Alguns lêem neles a emergência de um novo naturalismo centrado no privilegiamento dos pressupostos biológicos do comportamento humano. Assim Konrad Lorenz ou a sociobiologia. Para

48 E. Wigner, ob. cit., p. 271.

49 G. Bateson, Mind and Nature, Londres, Fontana, 1985.

50 Cf. também M. Bowen, "The Ecology of Knowledge: linking the natural and social sciences", Geoforum 16 (1985), p. 213 e segs. 
estes, a superação da dicotomia ciências naturais/ciências sociais ocorre sob a égide das ciências naturais. Contra esta posição pode objetar-se que ela tem do futuro a mesma concepção com que as ciências naturais autojustificam, no seio do paradigma dominante, $o$ seu prestígio científico, social e político e, por isso, só vê do futuro aquilo em que ele repete o presente. Se, pelo contrário, numa reflexão mais aprofundada, atentarmos no conteúdo teórico das ciências que mais têm progredido no conhecimento da matéria, verificamos que a emergente inteligibilidade da natureza é presidida por conceitos, teorias, metáforas e analogias das ciências sociais. Para não irmos mais longe, quer a teoria das estruturas dissipativas de Prigogine quer a teoria sinergética de Haken explicam o comportamento das partículas através dos conceitos de revolução social, violência, escravatura, dominação, democracia nuclear, todos eles originários das ciências sociais (da sociologia, da ciência política, da história, etc.). 0 mesmo sucede, ainda no campo da física teórica, com as teorias de Capra sobre a relação entre física e psicanálise, os padrões da matéria e os padrões da mente concebidos como reflexos uns dos outros. Apesar de estas teorias diluírem as fronteiras entre os objetos da física es objetos da biologia, foi sem dúvida no domínio desta última que os modelos explicativos das ciências sociais mais se enraizaram nas décadas recentes. Os conceitos de teleomorfismo, autopoiesis, auto-organização, potencialidade organizada, originalidade, individualidade, historicidade, atribuem à natureza um comportamento humano. Lovelock, em livro recente sobre as ciências da vida, afirma que os nossos corpos são constituídos por cooperativas de células 51 .

Que os modelos explicativos das ciências sociais vêm subjazendo ao desenvolvimento das ciências naturais nas últimas décadas prova-se, além do mais, pela facilidade com que as teorias físico-naturais, uma vez formuladas no seu domínio específico, se aplicam ou aspiram aplicar-se no domínio social. Assim, por exemplo, Peter Allen, um dos mais estreitos colaboradores de Prigogine, tem vindo a aplicar a teoria das estruturas dissipativas aos processos econômicos e à evolução das cidades e das regiões 52 . E Haken salienta as potencialidades da sinergética para explicar situações revolucionárias na sociedade 53 . Ė como se o dito de Durkheim se tivesse invertido e em vez de serem os fenômenos sociais a ser estudados como se fossem fenômenos naturais, são os fenômenos naturais estudados como se fossem fenômenos sociais.

O fato de a superação da dicotomia ciências naturais/ciências sociais ocorrer sob a égide das ciências sociais não é, contudo, suficiente para caracterizar o modelo de conhecimento no paradigma emergente. É que, como disse atrás, as próprias ciências sociais constituíram-se no século XIX segundo os modelos de racionalidade das ciências naturais clássicas e, assim, a égide das ciências sociais, afirmada sem mais, pode revelar-se ilusória. Referi contudo que a constituição das ciências sociais teve lugar segundo duas vertentes: uma mais dire tamente vinculada à epistemologia e à metodologia positivistas das ciências naturais, e outra, de vocação antipositivista, caldeada numa tradição filosofica complexa, fenomenológica, interacionista, mito-simbólica, hermenêutica, existencialista, pragmática, reivindicando a especificidade do estudo da sociedade mas tendo de, para isso, pressupor uma concepção mecanicista da natureza. A pujança desta segunda vertente nas duas últimas décadas é indicativa de ser ela o modelo de ciências sociais que, numa época de revolução científica, transporta a marca pós-moderna do paradigma emergente. Trata-se, como referi também, de um modelo de transição, uma vez que define

$51 J$. E. Lovelock, Gaia : a New Look at Life on Earth. Oxford, Oxford University Press.

52 P. Allen, "The Evolutionary Paradigm of Dissipative Structures', in E. Jantsch (org.), The Evolutionary Vision, cit., p. 25, e segs.

53 H. Haken, "Synergetics - An Interdisciplinary Approach to Phenomena of Self-Organization", Geoforum 16 (1985), p. 205 e segs. 
a especificidade do humano por contraposição a uma concepção da natureza que as ciências naturais hoje consideram ultrapassada, mas é um modelo em que aquilo que o prende ao passado é menos forte do que aquilo que o prende ao futuro. Em resumo, à medida que as ciências naturais se aproximam das ciências sociais estas aproximam-se das humanidades. 0 sujeito, que a ciência moderna lançara na diáspora do conhecimento irracional, regressa investido da tarefa de fazer erguer sobre si uma nova ordem científica.

Que este é o sentido global da revolução científica que vivemos, é também sugerido pela reconceptualização em curso das condições epistemológicas e me todológicas do conhecimento cientifico social. Referi acima alguns dos obstáculos à cientificidade das ciências sociais, os quais, segundo o paradigma ainda dominante, seriam responsáveis pelo atraso das ciências sociais em relação às ciências naturais. Sucede contudo que, também como referi, o avanço do conhecimento das ciências naturais e a reflexão epistemológica que ele tem suscitado têm vindo a mostrar que os obstáculos ao conhecimento científico da sociedade e da cultura são de fato

A concepção humanística das ciências sociais enquanto agente catalisador da progressiva fusão das ciências naturais e ciências sociais coloca

a pessoa, enquanto autor e sujeito do mundo, no centro do conhecimento, mas, ao contrário das humanidades tradicionais, coloca o que hoje designamos por natureza no centro da pessoa. Não há natureza humana porque toda a natureza é humana. condições do conhecimento em geral, tanto científico-social como científiconatural. Ou seja, o que antes era a causa do maior atraso das ciências sociais é hoje o resultado do maior avanço das ciências naturais. Daí também que a concepção de Thomas Kuhn sobre o caráter pré-paradigmático (isto é, menos desenvolvido) das ciências sociais 54 , que eu, aliás, subscrevi e reformulei noutros escritos 55 , tenha de ser abandonada ou profundamente revista.

A superação da dicotomia ciências naturais/ciências sociais tende assim a revalorizar os estudos humanísticos. Mas esta revalorização não ocorrerá sem que as humanidades sejam, elas também, profundamente transformadas. $\mathrm{O}$ que há nelas de futuro é o terem resistido à separação sujeito/objeto e o terem preferido a compreensão do mundo à manipulação do mundo. Este núcleo genuíno foi, no entanto, envolvido num anel de preocupações mistificatórias (o esoterismo' nefelibata e a erudição balofa). $\mathbf{O}$ ghetto a que as humanidades se remeteram foi em parte uma estratégia defensiva contra 0 assédio das ciências sociais, armadas do viés cientista triunfalmente brandido. Mas foi também o produto do esvaziamento que sofreram em face da ocupação do seu espaço pelo modelo cientista. Foi assim nos estudos históricos com a história quantitativa, nos estudos jurrdicos com a ciência pura do direito e a dogmática jurídica, nos estudos filológicos, literários e lingüísticos com o estruturalismo. Há que recuperar esse núcleo genuíno e pô-lo ao serviço de uma reflexão global sobre o mundo. 0 tex to sobre que sempre se debruçou a filologia é uma das analogias matriciais com que se construirá no paradigma emergente o conhecimento sobre a sociedade e a natureza.

A concepção humanística das ciências sociais en quanto agente catalisador da progressiva fusão das ciências naturais e ciências sociais coloca a pessoa, enquanto autor e sujeito do mundo, no centro do conhecimento, mas, ao contrário das humanidades tradicionais, coloca o que hoje designamos por natureza no centro da pessoa. Não há natureza humana porque toda a natureza é humana. E pois necessário descobrir categorias de inteligibilidade globais, conceitos quentes que derretam as fronteiras em que a ciência moderna dividiu e encerrou a realidade. A ciência pós-moderna é uma ciência assumidamente analógica que conhece o que conhece pior através do que conhece melhor. Já mencionei a analogia textual e julgo que tanto a analogia lúdica como a analogia dramática, como ainda a analogia biográfica, figurarão entre as categorias matriciais do paradigma emergente: 0 mundo, que hoje é natural ou social e amanhã será ambos, visto como um texto, como um jogo, como um palco ou ainda como autobiografia. Clifford Geertz refere algumas destas analogias

54 T. Kuhn, The Structure of Scientific Revolutions. Chicago, University of Chicago Press, 1962, passim.

55 Boaventura de Sousa Santos, ob. cit., p. 29 e segs. 
humanísticas e restringe o seu uso às ciências sociais, enquanto eu as concebo como categorias de inteligibilidade universais 56 . Nāo vira longe o dia em que a física das partículas nos fale do jogo entre as partículas, ou a biologia nos fale do teatro molecular ou a astrofísica do texto celestial, ou ainda a química da biografia das reações químicas. Cada uma destas analogias desvela uma ponta do mundo. A nudez total, que será sempre a de quem se vê no que vê, resultará das configurações de analogias que soubermos imaginar: afinal, o jogo pressupбe um palco, o palco exercita-se com um texto e o texto é a autobiografia do seu autor. Jogo, palco, texto ou biografia, o mundo é comunicação e por isso a logica existencial da ciência pós-moderna é promover a "situação comunicativa" tal camo Habermas a concebe. Nessa situação confluem sentidos e constelaçôes de sentido vindos, tal qual rios, das nascentes das nossas práticas locais e arrastando consigo as areias dos nossos percursos moleculares, individuais, comunitários, sociais e planetários. Não se trata de uma amálgama de sentido (que não seria sentido mas ruido), mas antes de interações e de intertextualidades organizadas em torno de projetos locais de conhecimento indiviso. Daqui decorre a segunda caracterrstica do conhecimento científico pós-moderno.

\section{Todo o conhecimento é local e total}

$\mathrm{Na}$ ciência moderna o conhecimento avança pela especialização. 0 conhecimento é tanto mais rigoroso quanto mais restrito e o objeto sobre que incide. Nisso reside, aliás, o que hoje se reconhece ser o dilema basico da ciência moderna: o seu rigor aumenta na proporção direta da arbitrariedade com que espartilha o real. Sendo um conhecimento disciplinar, tende a ser um conhecimento disciplinado, isto $\hat{\epsilon}$, segrega uma organização do saber orientada para policiar as fronteiras entre as disciplinas e reprimir os que as quiserem transpor. E hoje reconhecido que a excessiva parcelização e disciplinarização do saber cientffico faz do cientista um ignorante especializado e que isso acarreta efeitos negativos. Esses efeitos são sobretudo visíveis no dominio das ciências aplicadas. As tecnologias preocupam-se hoje com o seu impacto destrutivo nos ecossistemas; a medicina verifica que a hiperespecialização do saber médico transformou o doente numa quadrícula scm sentido quando, de fato, nunca estamos doentes senão em geral; a farmácia descobre o lado destrutivo dos medicamentos, tanto mais destrutivos quanto mais especificos, e procura uma nova lógica de combinação química atenta aos equilrbrios orgânicos; o direito, que reduziu a complexidade da vida jurŕdica à secura da dogmática, redescobre o mundo filosófico e sociológico em busca da prudência perdida; a economia, que legitimara o reducionismo quantitativo e tecnocrático com o pretendido êxito das previsões econômicas, é forçada a reconhecer, perante a pobreza dos resultados, que a qualidade humana e sociológica dos agentes e processos económicos entra pela janela depois de ter sido expulsa pela porta; para grangear o reconhecimento dos utentes (que, públicos ou privados, institucionais ou individuais, sempre estiveram numa posição de poder em relação aos analisados) a psicologia aplicada privilegiou instrumentos expeditos e facilmente manuseáveis, como sejam os testes, que reduziram a riqueza da personalidade às exigências funcionais de instituições unidimensionais.

Os males desta parcelização do conhecimento e do reducionismo arbitrário que transporta consigo são hoje reconhecidos, mas as medidas propostas para os corrigir acabam em geral por os reproduzir sob outra forma. Criam-se novas disciplinas para resolver os problemas produzidos pelas antigas e por essa via reproduz-se o mesmo modelo de cientificidade. Apenas para dar um exemplo, o médico generalista, cuja ressurreição visou compensar a hiperespecialização médica, corre o risco de ser convertido num especialista ao lado dos demais. Este efeito perverso revela que não há solução para este problema no seio do paradigma

56 C. Geertz, Local Knowledge. Further Essays in Interpretative Anthropology. Nova Iorque, Basic Books, 1983, p. 19 e segs. 
dominante e precisamente porque este último é que constitui o verdadeiro problema de que decorrem todos os outros.

No paradigma emergente 0 conhecimento $e$ total, tem como horizonte a totalidade universal de que fala Wigner ou a totalidade indivisa de que fala Bohm. Mas sendo total, é também local. Constitui-se em redor de temas que em dado momento são adotados por comunidades interpretativas concretas como projetos de vida.locais, sejam eles reconstituir a história de um lugar, manter um espaço verde, construir um computador adequado às necessidades locais, fazer baixar a taxa de mortalidade infantil, inventar um novo instrumento musical, erradicar uma doença, etc., etc. A fragmentação pós-moderna não é disciplinar e sim temática. Os temas são galerias por onde os conhecimentos progridem ao encontro uns dos outros. Ao contrário do que sucede no paradigma atual, o conhecimento avança à medida que o seu obje to se amplia, ampliação que, como a da árvore, procede pela diferenciação e pelo alastramento das raízes em busca de novas e mais variadas interfaces.

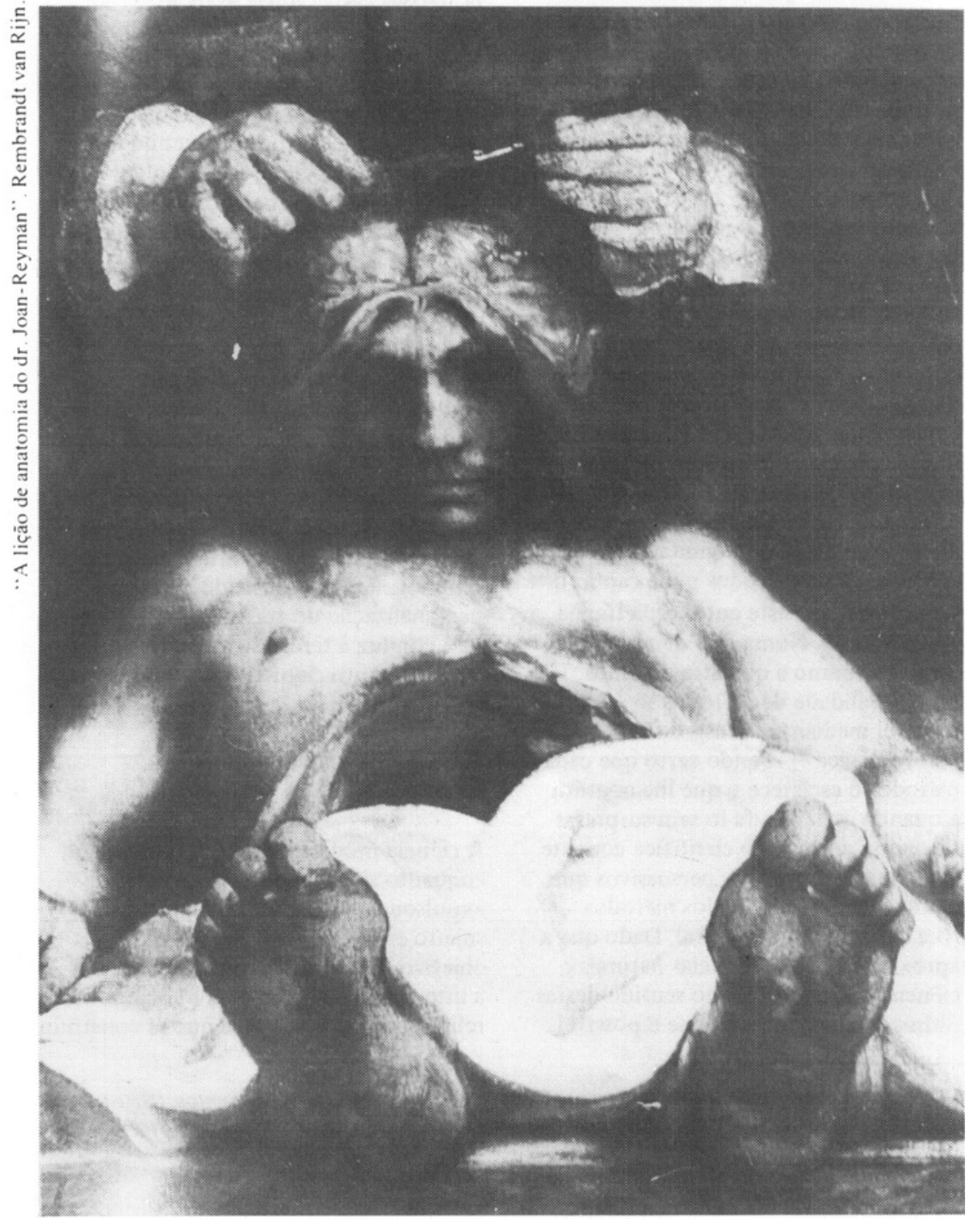


Mas sendo local, o conhecimen to pós-moderno é também total porque reconstitui os projetos cognitivos locais, salientando-lhes a sua exemplaridade, e por essa via transforma-os em pensamento total ilustrado. A ciência do paradigma emergente, sendo, como deixei dito acima, assumidamente analogica, $\hat{\epsilon}$ também assumidamente tradutora, ou seja, incentiva os conceitos $e$ as teorias desenvolvidos localmente a emigrarem para outros lugares cognitivos, de modo a poderem ser utilizados fora do seu contexto de origem. Este procedimento, que é reprimido por uma forma de conhecimento que concebe através da operacionalização e generaliza através da quantidade e da uniformização, será normal numa forma de conhecimento que concebe através da imaginação e generaliza através da qualidade e da exemplaridade.

O conhecimento pós-moderno, sendo total, não é determinístico, sendo local, não é descritivista. E um conhecimento sobre as condições de possibilidade. As condições de possibilidade da ação humana projetada no mundo a partir de um espaço-tempo local. Um conhecimento deste tipo é relativamente imetódico, constitui-se a partir de uma pluralidade metodológica. Cada método é uma linguagem e a realidade responde na língua em que é perguntada. Só uma constelação de métodos pode captar o silêncio que persiste entre cada língua que pergunta. Numa fase de revolução cientifica como a que atravessamos, essa pluralidade de métodos só é possível mediante transgressão metodológica 57 . Sendo certo que cada método só esclarece o que lhe convém e quando esclarece fá-lo sem surpresas de maior, a inovação cientifica consiste em inventar contextos persuasivos que conduzam à aplicação dos métodos fora do seu habitat natural. Dado que a aproximação entre ciências naturais e ciências sociais se fará no sentido destas últimas, caberá especular se é possível, por exemplo, fazer a análise filológica de um traçado urbano, entrevistar um pássaro ou fazer observação participante entre computadores.

A transgressão metodológica repercute-se nos estilos e gêneros literários que presidem à escrita cientifica. A ciência pos-moderna não segue um estilo unidimensional, facilmente identificável; o seu estilo é uma configuração de estilos construrda segundo o critério e a imaginação pessoal do cientista. A tolerância discursiva é o outro lado da pluralidade metodológica. $\mathrm{Na}$ fase de transição em que nos encontramos são já visíveis fortes sinais deste processo de fusão de estilos, de interpenetrações entre cânones de escrita. Clifford Geertz estuda o fenômeno nas ciências sociais e apresenta alguns exemplos: investigação filosófica parecendo crítica literária no estudo de Sartre sobre Flaubert; fantasias barrocas sob a forma de observações empíricas (a obra de Jorge Luis Borges); parábolas apresentadas como investigações etnográficas (Carlos Castañeda); estudos epistemológicos sob a forma de textos politicos (a obra Against Method de Paul Feyerabend) 58 . E como Geertz, podemos perguntar se Foucault é historiador, filbsofo, sociólogo ou cientista político. A composição transdisciplinar e individualizada para que estes exemplos apontam sugerem um movimento no sentido da maior personalização do trabalho cientifico. Isto conduz à terceira característica do conhecimento científico no paradigma emergente.

\section{Todo o conhecimento é autoconhecimento}

A ciência moderna consagrou o homem enquanto sujeito epistêmico mas expulsou-o, tal como a Deus, enquanto sujeito emprico. Um conhecimento objetivo, fatual e rigoroso não tolerava a in terferência dos valores humanos ou religiosos. Foi nesta base que se construiu

57 Sobre o conceito de transgressāo metodolbgica cf. Boaventura de Sousa Santos, "Science and Politics: doing research in Rio's squatter settlements", in R. Luckham (org.). Law and Social Enquiry : case studies of research. Uppsala, Scandinavian Institute of African Studies, 1981, p. 275 e segs.

58 C. Geertz, ob. cit., p. 20. 
a distinção dicotômica sujeito/objeto. No entanto', a distinção sujeito/objeto nunca foi tão pacifica nas ciências sociais quanto nas ciências naturais $\mathrm{e} a$ isso mesmo se atribuiu, como disse, 0 maior atraso das primeiras em relação às segundas. Afinal, os objetos de estudo eram homens e mulheres como os que os estudavam. A distinção epistemológica entre sujeito e objeto teve de se articular metodologicamente com a distância empírica entre sujeito e objeto. Ișto mesmo se torna evidente se compararmos as estratégias metodológicas da antropologia cultural e social, por um lado, e da sociologia, por outro. $\mathrm{Na}$ antropologia, a distância empírica entre o sujeito e o pbjeto era enorme. $O$ sujeito era o an tropólogo, o europeu civilizado, o objeto era o povo primitivo ou selvagem. Neste caso, a distinção sujeito/obje to aceitou ou mesmo exigiu que a distância fosse relativamente encurtada atrạvés do uso de metodologias que obrigavam a uma maior intimidade com o objeto, ou seja, o trabalho de campo etnográfico, a observação participante. Na sociologia, ao contrário, era pequena ou mesmo nula a distância empírica entre o sujeito e objeto: eram cientistas europeus a estudar os seus concidadãos. Neste caso, a distinção epistemológica obrigou a que esta distância fosse aumentada através do uso de metodólogias de distanciamento: por exemplo, o inquérito sociológico, a análise documental e a entrevista estruturada.

A antropologia, entre a descolonização do pós-guerra e a guerra do Vietnam, e a sociologia, a partir do final dos anos sessenta, foram levadas a questionar este status quo metodológico e as noçōes de distância social em que ele assentava. De repente, os selvagens foram vistos dentro de nós nas nossas sociedades e a sociologia passou a utilizar com mais

No domínio das ciências físico-naturais, o regresso do sujeito fora já anunciado pela mecânica quântica ao demonstrar que o ato de conhecimento

e o produto do conhecimento eram inseparáveis. intensidade métodos anteriormente quase monopolizados pela antropologia (a observação participante), ao mesmo tempo que nesta última os objetos passavam à ser concidadãos, membros de pleno direito da Organização das Nações Unidas, e tinham de ser estudados segundo métodos sociologgicos. As vibrações destes movimentos nà distinção sujeito/objeto nas ciências sociais vieram a explodir no período pós-eștruturalista.

No domínio das ciências físico-naturais, o regresso do sujeito fora já anunciado pela mecânica quântica' ao demonstrar que $o$ ato de conhecimento e o produto do conhecimento eram inseparáveis. Os avanços da microfísica, da astrofísica e da biologia das últimas décadas restituíram à natureza as propriedades de que a ciência moderna a expropriara. $O$ aprofundamento do conhecimento conduzido segundo a matriz materialista veio a desembocar num conhecimento idealista. A nova dignidade da natureza mais se consolidou quando se verificou que o desenvolvimento tecnológico desordenado nos tinha separado da natureza em vez de nos unir a ela e que a exploração da natureza tinha sido o verculo da exploração do homem. O desconfórto que a distinção sujeito/ objeto sempre tinha provocado nas ciências sociais propagava-se assim às ciências naturais. $\mathbf{O}$ sujeito regressava na veste dó objeto. Aliás, os conceitos de "mente imanente", "mente mais ampla" e "mente coletiva" de Bateson e outros constituem notícias dispersas de que 0 outro foragido da ciência moderna, Deus, pode estar em vias de regressar.

Regressará transfigurado, sem nada de divino sénáo o nosso desejo de harmonia e comunhão com a natureza que nos rodeia e que, vemos agora, é o mais intimo de nós. Uma nova gnose está em gestação.

Parafraseando Clausewitz, podemos afirmar hoje que o objeto é a continuação do sujeito por outros meios. Por isso, todo o conhecimento científico é autoconhecimento. A ciência não descobre, cria, e $o$ ato criativo protagonizado por cada cientista e pela comunidade cientifica no seu conjunto tem de se conhecer intimamente antes que conheça o que com ele se conhece do real. Os pressupostos metafísicos, os sistemas de crenças, os jứzos de valor não estão antes nem depois da explicação cientffica da natureza ou da sociedade. São parte integrante dessa mesma explicação. A ciência moderna não é a única explioação possível da realidade e não há sequer qualquer razão científica para a considerar melhor que as explicações alternativas da metafísica, 
da astrologia, da religião, da arte ou da poesia. A razão por que privilegiamos hoje uma forma de conhecimento assente na previsão e no controle dos fenômenos nada tem de científico. E o juízo de valor. A explicação cientifica dos fenômenos é autojustificação da ciência enquanto fenomeno central da nossa contemporaneidade. A ciência é, assim, autobiográfica.

A consagração da ciência modema nestes ultimos quatrocentos anos naturalizou a explicação do real, a ponto de não o podermos conceber senão nos termos por ela propostos. Sem as categorias de espaço, tempo, matéria e número - as metáforas cardeais da física moderna, segundo Roger Jones - sentimo-nos incapazes de pensar, mesmo sendo já hoje capazes de as pensarmos como categorias convencionais, arbitrárias, metafóricas. Este processo de naturalização foi lento e, no ínicio, os protagonistas da revolução cientffica tiveram a noção clara que a prova intima das suas convicçбes pessoais precedia $e$ dava coerência às provas externas que desenvolviam. Descartes mostra melhor que ninguém o caráter autobiografico da ciência. Diz, no Discurso do Método: "Gostaria de mostrar, neste Discurso, que caminhos segui; $e$ de nele representar a minha vida como num quadro, para que cada qual a possa julgar, e para que, sabedor das opiniões que sobre ele foram expendidas, um novo meio de me instruir se venha juntar àqueles de que costumo servir-me" 59. Hoje sabemos ou suspeitamos que as nossas trajetorias de vida pessoais e coletivas (enquanto comunidades cientificas) e os valores, as crenças e os prejurzos que transportam são a prova Intima do nosso conhecimento, sem o qual as nossas investigaçōes

laboratoriais ou de arquivo, os nossos cálculos ou os nossos trabalhos de campo constituiriam um emaranhado de diligências absurdas sem fio nem pavio. No entanto, este saber, suspeitado ou insuspeitado, corre hoje subterraneamente, clandestinamente, nos não-ditos dos nosso trabalhos cientŕficos.

No paradigma emergente, $o$ caráter autobiográfico e auto-referenciável da ciência é plenamente assumido. A ciência moderna legou-nos um conhecimento funcional do mundo que alargou extraordinariamente as nossas perspectivas de sobrevivência. No futuro não se tratará tanto de sobreviver como de saber viver. Para isso é necessária uma outra forma de conhecimento, um conhecimento compreensivo e Intimo que não nos separe e antes nos una pessoalmente ao que estudamios. A incerteza do conhecimento, que a ciência moderna sempre viu como limitação técnica destinada a sucessivas superações, transforma-se na chave do entendimento de um mundo que mais do que controlado tem de ser contemplado. Não se trata do espanto medieval perante uma realidade hostil possurda do sopro da divindade, mas antes da prudência perante um mundo que, apesar de domesticado, nos mostra cada dia a precaridade do sentido da nossa vida por mais segura que esteja ao nível da sobrevivência. A ciência do paradigma emergente é mais contemplativa do que ativa. A qualidade do conhecimento afere-se menos pelo que ele controla ou faz funcionar no mundo exterior do que pela satisfação pessoal que dá a quem a ele acede e o partilha.

A dimensão estética da ciência tem sido reconhecida por cientistas e filosofos da ciência, de Poincaré a Kuhn, de Polanyi a Popper. Roger Jones considera que o sistema de Newton é tanto uma obra de arte como uma obra de ciência 60 . A criação científica no paradigma emergente assume-se como próxima da criação literária ou artística, porque à semelhança destas pretende que a dimensão ativa da transformação do real (o escultor a trabalhar a pedra) seja subordinada à contemplação do resultado (a obra de arte). Por sua vez, o discurso cientffico aproximar-se-á cada vez mais do discurso da critica literária. De algum modo, a crítica literária anuncia a subversão da relação sujeito/objeto que o paradigma emergente pretende operar. Na crítica literária, o objeto do

59 Descartes, ob. cit., p. 6.

60 R. Jones, ob. cit., p. 41. 
estudo, como se diria em termos cientificos, sempre foi, de fato, um supersujeito (um poeta, um

romancista , um dramaturgo) face ao qual o crítico não passa de um sujeito ou autor secundário. E certo que, em tempos recentes, 0 crítico tem tentado sobressair no confronto com o escritor estudado a ponto de se poder falar de uma batalha pela supremacia travada entre ambos. Mas porque se trata de uma batalha, a relação é entre dois sujeitos e não entre um sujeito e um objeto. Cada um é a tradução do outro, ambos criadores de textos, escritos em línguas distintas ambas conhecidas e necessárias para aprender a gostar das palavras e do mundo.
Assim ressubjetivado, o conhecimento cientrfico ensina a viver e traduz-se num saber prático. Dar a quarta e ultima característica da ciência pós-moderna.

\section{Todo o conhecimento cientifico visa constituir-se num novo senso comum}

Já tive ocasião de referir que o fundamento do estatuto privilegiado da racionalidade cientifica não é em si mesmo científico. Sabemos hoje que a ciência moderna nos ensina pouco sobre a nossa maneira de estar no mundo e que esse pouco, por mais que se amplie, será sempre exíguo porque a exigüidade está inscrita na forma de conhecimento que ele constitui. A ciência moderna produz

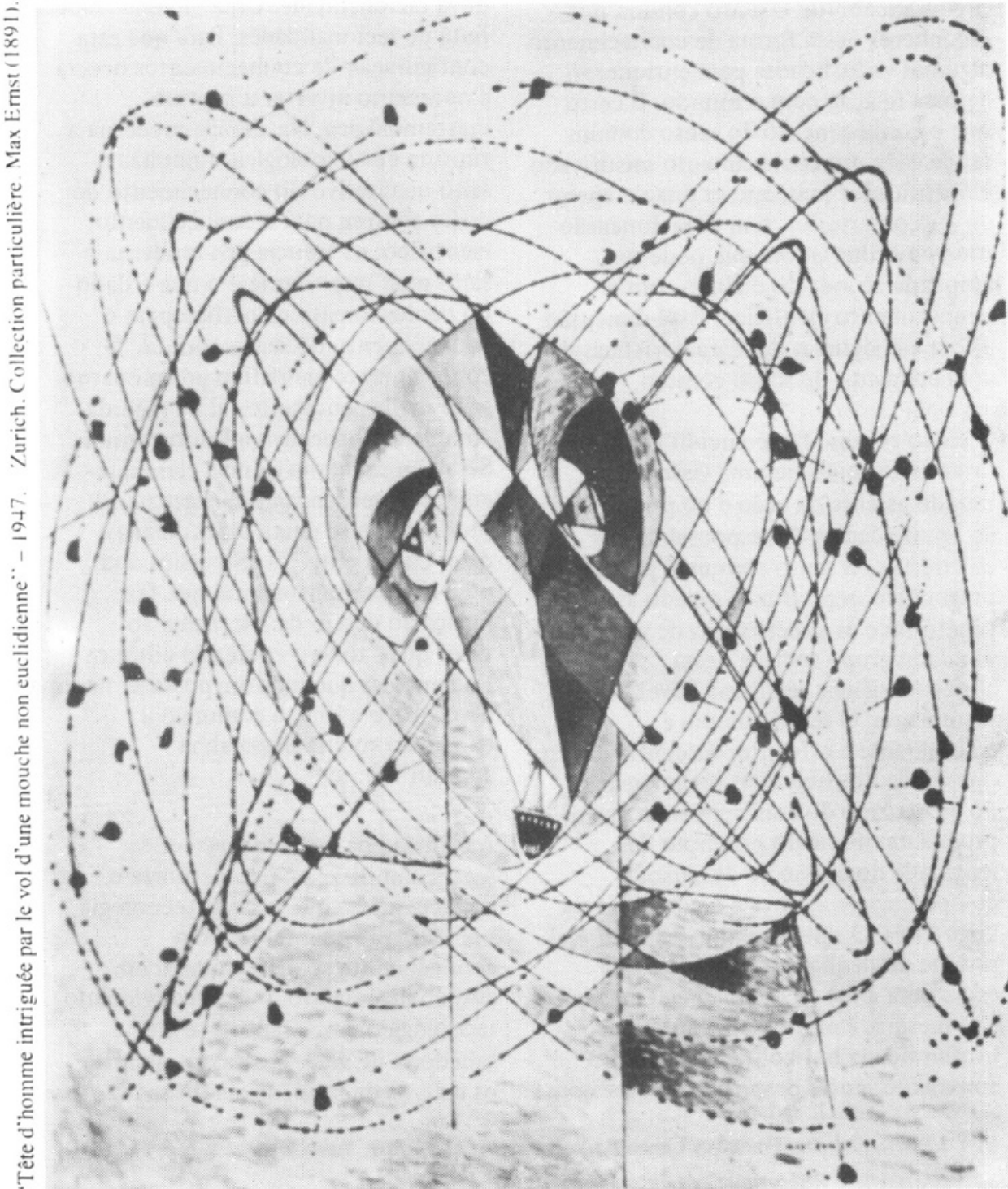


conhecimentos e desconhecimentos. Se faz do cientista um ignorante especializado faz do cidadão comum um ignorante generalizado.

Ao contrário, a ciência pós-moderna sabe que nenhuma forma de conhecimento é, em si mesma, racional; só a configuração de todas elas é racional. Tenta, pois, dialogar com outras formas de conhecimento deixando-se penetrar por elas. A mais importante de todas é o conhecimento do senso comum, $o$ conhecimento vulgar e prático com que no quotidiano orientamos as nossas ações e damos sentido à nossa vida. $\mathrm{A}$ ciência moderna construiu-se contra o senso comum que considerou superficial, ilusório e falso. A ciência pós-moderna procura reabilitar o senso comum por reconhecer nesta forma de conhecimento algumas virtualidades para enriquecer a nossa relação com o mundo. E certo que o conhecimento do senso comum tende a ser um conhecimento mistificado e mistificador mas, apesar disso e apesar de ser conservador, tem uma dimensão utópica e libertadora que pode ser ampliada através do diálogo com o conhecimento científico. Essa dimensão aflora em algumas das características do conhecimento do senso comum.

O senso comum faz coincidir causa e intenção; subjaz-lhe uma visão do mundo assente na ação e no princípio da criatividade e da responsabilidade individuais. $O$ senso comum é prático e pragmático; reproduz-se colado às trajetórias e às experiências de vida de um dado grupo social e nessa correspondência se afirma fiável e securizante. $O$ senso comum é transparente e evidente; desconfia da opacidade dos objetivos tecnológicos e do esoterismo do conhecimento que os projeta em nome do princípio da igualdade do acesso ao discurso, à competência cognitiva e à competência lingüística. $O$ senso comum é superficial porque desdenha das estruturas que estão para além da consciência, mas, por isso mesmo, é exímio em captar a profundidade horizontal das relações conscientes entre pessoas e entre pessoas e coisas. $O$ senso comum é indisciplinar e imetódico; não resulta de uma prática especificamente orientada para o produzir; reproduz-se espontaneamente no suceder quotidiano da vida. $O$ senso comum aceita $o$ que existe tal como existe; privilegia a ação que não produza rupturas significativas no real. Por altimo, o senso comum é retórico e metafórico; não ensina, persuade.

A luz do que ficou dito atrás sobre o paradigma emergente, estas características do senso comum têm uma virtude antecipatória. Deixado a si mesmo, o senso comum é conservador e pode legitimar prepotências, mas in terpenetrado do conhecimento cientifico pode estar na origem de uma nova racionalidade. Uma racionalidade feita de racionalidades. Para que esta configuração de conhecimentos ocorra é necessário inverter a ruptura epistemológica. $\mathrm{Na}$ ciência moderna a ruptura epistemológica simboliza o salto qualitativo do conhecimento do senso comum para o conhecimento científico; na ciência pós-moderna o salto mais importante é o que é dado do conhecimento científico para o conhecimento do senso comum. 0 conhecimento cientifico pos-moderno só se realiza enquanto tal na medida em que se converte em senso comum. Só assim será uma ciência clara que cumpre a sentença de Wittgenstein, "tudo o que se deixa dizer deixa-se dizer claramente" 61 . Só assim será uma ciência transparente que faz justiça ao desejo de Nie tzsche ao dizer que "todo o comércio entre os homens visa que cada um possa ler na alma do outro, e a língua comum é a expressão sonora dessa alma comum" 62 .

A ciência pós-moderna, ao sensocomunizar-se, não despreza o conhecimento que produz tecnologia, mas entende que, tal como o conhecimento se deve traduzir em autoconhecimento, o desenvolvimento tecnológico deve traduzir-se em sabedoria de vida. É esta que assinala os' marcos da prudência à nossa aventura

61 L. Wittgenstein, Tractatus Logico-Philosophicus! Frankfurt, Suhrkamp, 1973, 4.116.

62 Nietzsche, "Rhetorique et Langage"; Poetique, S (191), p. 139. 
cientifica. A prudência é a insegurança assumida e controlada. Tal como Descartes, no limiar da ciência moderna, exerceu a dúvida em vez de a sofrer, nós, no limiar da ciência pós-moderna, devemos exercer a insegurança em vez de a sofrer.

$\mathrm{Na}$ fase de transição e de revolução cientifica, esta insegurança resulta ainda do fato de a nossa reflexao epistemológica ser muito mais avançada e sofisticada que a nossa prática científica. Nenhum de nós pode neste momento visualizar projetos concretos de investigação que correspondam in teiramente ao paradigma emergente que aqui delineei. $E$ isso é assim precisamente por estarmos numa fase de transição. Duvidamos suficientemente do passado para imaginarmos o futuro, mas vivemos demasiadamente o presente para podermos realizar nele o futuro. Estamos divididos, fragmentados. Sabemo-nos a caminho mas não exatamente onde estamos na jornada. A condição epistemológica da ciência repercute-se na condição existencial dos cientistas. Afinal, se todo o conhecimento $\epsilon$ autoconhecimento, também todo o desconhecimento é autodesconhecimento.

Boaventura de Sousa Santos é cientista social, com formação em Direito. professor-convidado da Universidade de Madison (Wisconsin), e da London School of Economics and Political

Science: ć professor-titular da Faculdade de Economia da Universidade de Coimbra e presidente do Centro de Documentação 25 de Abril daquela universidade. Ao longo dos últimos vinte anos, o prof. Boaventura escreveu extensivamente sobre a sociologia do dircito e do Estado, tanto nas sociedades capitalistas centrais, como nas sociedades periféricas. Os resultados das pesquisas cmpíricas que realizou nas favelas do Rio de Janeiro e Recife, em Portugal e em Cabo Verde, suscitaram-lhe reflexōes teóricas publicadas nas mais significativas revistas científicas internacionais. Sobre o Brasil, onde desenvolveu pesquisas de campo na favela do Jacarezinho (RJ), escreveu um de seus principais livros: The law of the opressed, publicado pela Universidade de Yale, em 1974, e pela "Law and Society Review", em 1977 (em vias de publicação pela editora da Universidade de Brasília). Boaventura de Sousa Santos participou das atividades do Instituto de Estudos Avançados como professor-visitante, nos meses de maio e junho de

1988 , e realizou vários estudos de sociologia e epistemologia da ciência, preparando, no IEA, uma monografia sobre $O$ social e o politico na transifäo pós-moderna.

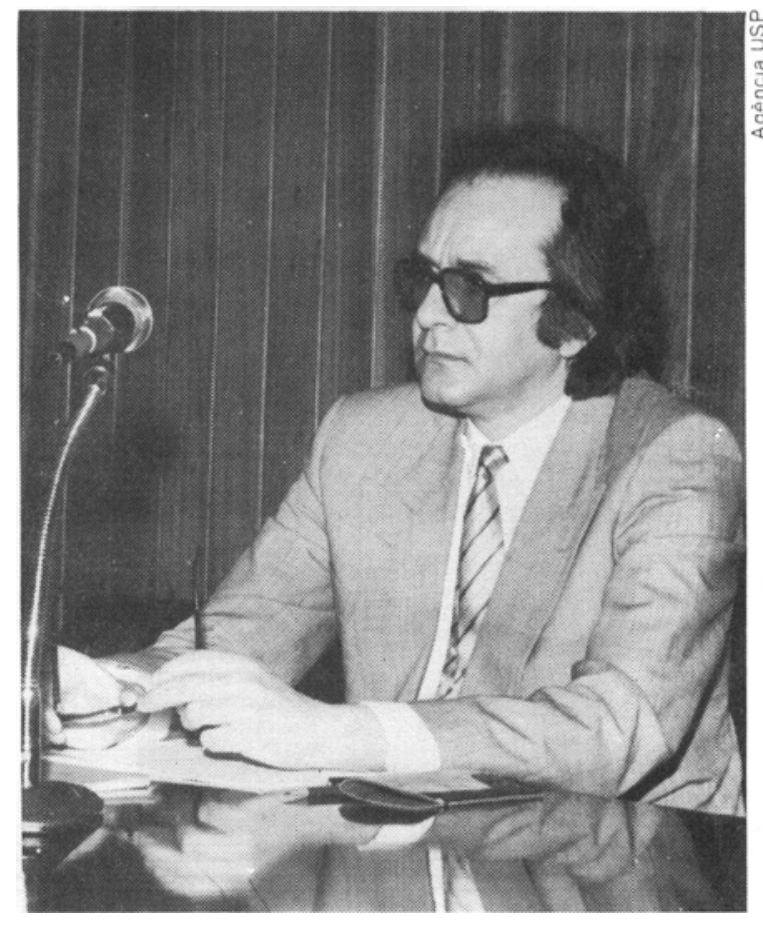

